\section{Las casas-torre bajomedievales. Análisis sistémico de un proceso de reestructuración espacial/territorial}

Agustín Azkarate Garai-Olaun, Ismael García Gómez Grupo de Investigación en Arqueología de la Arquitectura, Universidad del País Vasco/Euskal Herriko Unibertsitatea

\begin{abstract}
Resumen
La torre banderiza es uno de los más relevantes elementos del patrimonio construido vasco. Diseminados por toda la geografía de la comunidad autónoma, se pueden encontrar ejemplos representativos de este tipo arquitectónico, característico de una convulsa etapa que se prolongó algo más allá del período de crisis bajomedieval (siglos XIV-XVI). Este trabajo pretende por un lado formular una propuesta interpretativa sistémica e integradora que, partiendo del análisis estratigráfico de las fábricas, muestre el peso específico de esta construcción como elemento de gestión de los recursos del territorio. Pero sobre todo, en las siguientes líneas se hace una decidida apuesta por una forma de entender la investigación histórico-arqueológica.
\end{abstract}

Palabras clave: Torres banderizas, Análisis estratigráfico, Análisis espacial, Análisis sistémico, Redes, Sistema Arquitectónico Banderizo, Lucha de bandos, Comunidad Autónoma Vasca.

\section{Abstract \\ The torre banderiza is one of the most relevant elements of Basque building heritage., Representative examples of this type of architecture can be found throughout the autonomous community, characteristic of a turbulent period which lasted a little longer than the low medieval crisis (14th to 16th centuries). This study sets out to formulate a systemic, interpretative and integrating proposal, based on stratigraphic stonework analysis, to show the specific relevance of this construction as an element of administering resources in the territory. But above all the work attempts to understand historical-archaeological research.}

Key words: Torres banderizas, Stratigraphic analysis, Spatial analysis, Systemic analysis, Networks, Banderizo Architectonic System, Bandos conflict, Basque Autonomous Community.

\section{EL SISTEMA ARQUITECTÓNICO BANDERIZO (S.A.B.). CONTEXTOS Y ELEMENTOS BÁSICOS}

\subsection{Contexto geográfico: el medio como activo}

En las diversas ocasiones en que nos hemos enfrentado al estudio arqueológico de una torre o casa-fuerte — por más que nuestra intención inicial fuera conocer la evolución constructiva de un edificio concreto- inevitablemente nos hemos visto en la necesidad de volver nuestra mirada hacia el entorno geográfico circundante. Con la experiencia acumulada hemos ido aceptando una realidad que se nos imponía tenazmente: es imposible comprender un edificio sin prestar atención al entorno en que se enclava. Tan imbricados están uno y otro que - de no mediar esa arraigada tradición que distingue netamente la arquitectura como uno de tantos artificios humanos - no parecería equivocado percibir aquella como otro producto más de la tierra, un fruto procedente del mismo sustrato geológico y labrado por el mismo clima, acaso vivo.

Esta idea ecosistémica — que aúna lo construido por la naturaleza con lo construido por el hombre- no es ilusoria, como de hecho el arqueólogo comprueba cotidianamente cuando se enfrenta al estudio de un elemento de la cultura material. Desde los propios materiales utilizados para elevar muros, hasta el emplazamiento escogido para la ubicación de una construcción, todo el edificio está condicionado por las posibilidades que ofrece su medio ambiente. No obstante, si queremos comprender lo edificado, no podemos guiarnos por una suerte de determinismo natural. Lo verdaderamente interesante consiste en el conocimiento de la dialéctica que se establece entre una sociedad y el entorno del que depende.

Antes de comenzar con nuestra exposición, señalaremos algunas de las claves sobre las que se cimienta nuestra forma de entender el territorio bajomedieval. Con ellas, trataremos de esbozar un marco conceptual que nos permita desarrollar nuestro discurso posterior:

1. Espacio polisémico: El espacio actúa al mismo tiempo como soporte, como medio geográfico, como recurso y como medio de producción. Creemos que la distinción de estas funciones permite una mayor operatividad del análisis histórico puesto que facilita la caracterización de los diversos agentes sociales que han intervenido en la producción del espacio, concretando su papel y permitiendo una mejor definición de las estrategias que los impulsan (SÁNCHEZ, 1991: 8).

2. Espacio heterogéneo: Los recursos naturales depositados en la superficie terrestre se encuentran repartidos de forma desigual. Esa heterogeneidad en la distribución de los recursos es un motivador de estrategias de apropiación y/o control, así como causa de conflicto entre grupos sociales o entre unidades geopolíticas. Promueve la circulación y del intercambio de bienes, pues las carencias de un territo- 


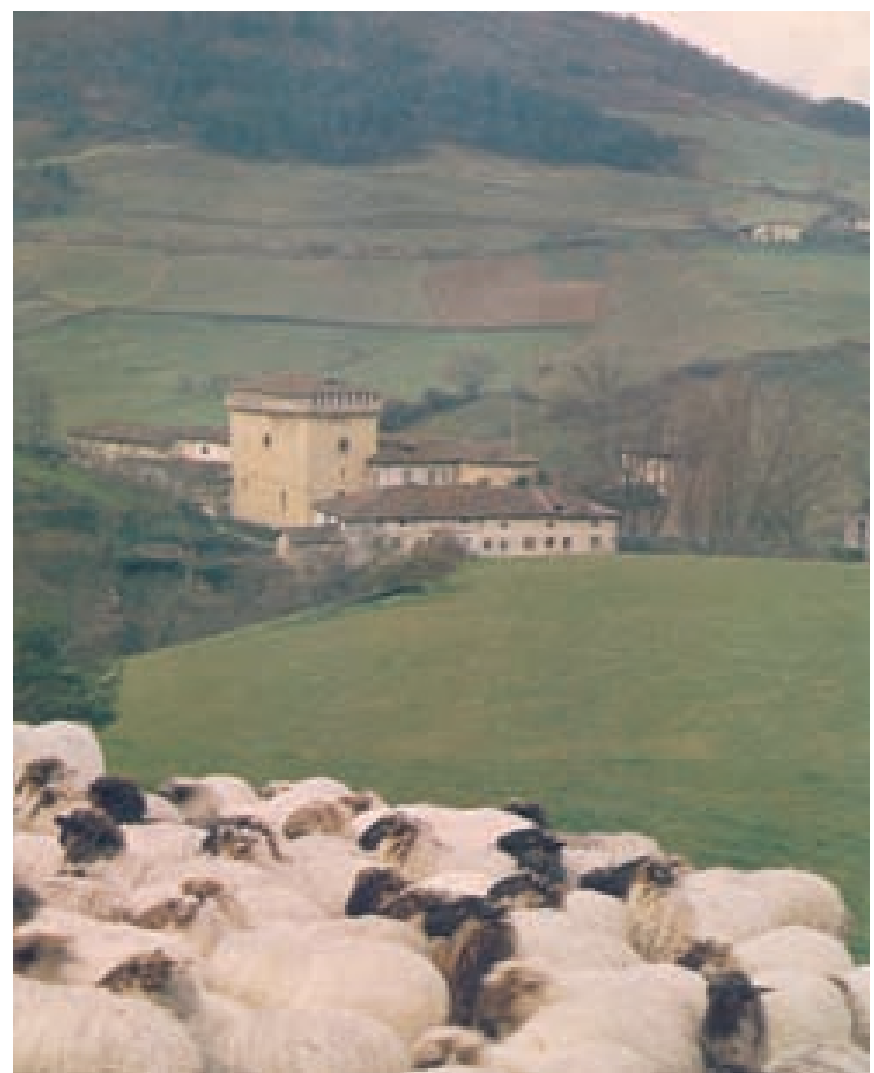

Torre de los Ayala en Quejana (Álava). Se sitúa en el fondo del valle, junto al río Izalde que lo surca. El espacio geográfico no es sólo soporte, no sólo un repositorio de recursos económicos (bosque, pastos, cursos fluviales, etc.) es también el medio que posibilita o impide las comunicaciones entre los diferentes grupos humanos. (Foto: Archivo Heraclio Fournier)

rio tienden a suplirse con los excedentes procedentes de otro (SÁnCHEZ, 1991: 73-74).

3. Espacio social. En sentido abstracto, el espacio físico natural propiamente dicho podría concebirse como un hecho material independiente del ser humano. Sin embargo, se convierte en un espacio socializado desde el momento en que aquél precisa del espacio geográfico, se sirve de él y lo transforma. (SÁNCHEZ, 1991: XII).

El marco físico que tomaremos como referencia a lo largo de este artículo será el de la Comunidad Autónoma del País Vasco, pues ha sido éste el contexto administrativo en el que, básicamente, venimos desarrollando nuestra actividad investigadora. No obstante, el fenómeno de la crisis bajomedieval - y la generalización de la conflictividad ligada a ella - no entiende de límites geopolíticos actuales, y por ello creemos que el ejemplo del espacio vasco podría ser extrapolable a los ámbitos geográficos limítrofes.

\subsection{Contexto histórico: la crisis bajomedieval}

Entre los investigadores que estudian la sociedad vasca bajomedieval y la conflictividad inherente a la misma, existe un amplio acuerdo en torno a un fenómeno de carácter troncal: el recrudecimiento de las luchas banderizas coincide con aquel período en que el grupo socialmente dominante - vale decir en nuestro caso, el de los parientes mayores - se enfrenta a crecientes dificultades para mantener su nivel de rentas (Díaz DE Durana, 1998: 41). Y a pesar de que el debate historiográfico al respecto se preocupa por diversas temáticas, una cuestión emerge constantemente en todos los análisis: la crisis bajomedieval —sea cual fuere su expresión social final- tiene origen en problemas de índole económica, los cuales incluso han sido conceptualizados como "primera crisis del feudalismo".

Hace algunos años G. Bois (2001: 74-82) esbozó un esquema con los principales rasgos sintomáticos de aquella depresión, a saber: un radical hundimiento demográfico, una acusada caída de la producción agrícola y el descenso de la producción industrial. Para este autor, guerra, peste y demás coyunturas catastróficas, sólo serían factores secundarios, consecuencias más que causas, aunque sin duda mecanismos amplificadores de la hecatombe.

La crisis sería una compleja conjunción de procesos: por un lado, el desplome demográfico que produjo una disminución de efectivos humanos para el trabajo de la tierra -obligando al abandono de las parcelas de terreno cultivado más periféricas-; por otro, la crisis de la producción industrial, que se tradujo en una patente deslocalización de la actividad artesana, la cual invirtió su tendencia de concentración en ámbito urbano, por una mayor dispersión territorial.

Sin embargo, subyaciendo en los fenómenos descritos, reside aún su causa última, la que Bois denomina como «deflación de larga duración». Un lento proceso que consistió en una paulatina contracción de la demanda y un deshinchamiento de la especulación inmobiliaria: «La presión demográfica y la escasez de tierras disponibles habían hecho sentir sus efectos. Sobre las parcelas más recientemente establecidas a censo, los señores habían exigido pagos más elevados. Lo mismo sucedía con el precio de la tierra y el montante de los arrendamientos, lo que había contribuido, dicho sea de paso, a la elevación de los precios agrícolas. Este movimiento no podía continuar indefinidamente ya que no era socialmente soportable» (BoIs, 2001:106).

La crisis, como todo proceso, es poliédrica, presenta múltiples caras. Así la aludida deflación, al tiempo que destruía, creaba, transformaba. No sería equivocado pensar que, tras una prolongada crisis en que la población se había reducido a la tercera parte, la configuración de nuevas formas de explotación agrícola o ganadera no podía sino beneficiarse de la mayor disponibilidad de espacio, favoreciendo el ensayo de nuevas fórmulas de apropiación del territorio. No todas ellas subsistirían en el tiempo, algunas desaparecerían, pero otras tuvieron la capacidad de adecuarse a las 
Esquema sintético de las principales relaciones sistémicas que mantienen las células productivas que quedan bajo el dominio de la torre

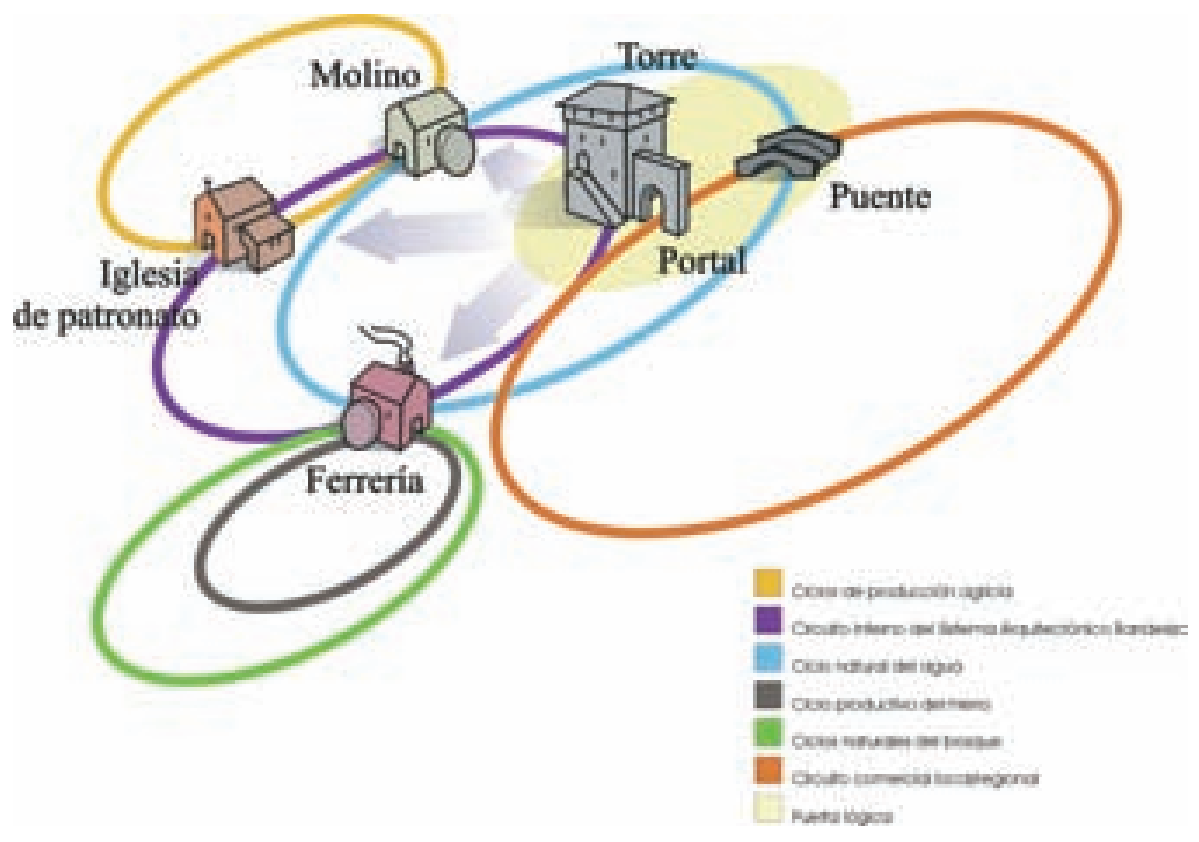

circunstancias del nuevo despegue de la economía europea en la segunda mitad del siglo XV.

Este es el contexto económico en el cual, volviendo al objeto que centra nuestro estudio, evoluciona la torre o casa-fuerte, que desde principios del siglo XIV hasta bien entrado el siglo XVI, será uno de los elementos distintivos — sin duda, clave funcional_ de un complejo sistema de apropiación, control y administración del territorio modelado sobre la dinámica socio-política generada por los parientes mayores, también conocidos como los señores de la tierra $^{1}$ (LEMA PUEYO et al., 2000).

\subsection{Las bases materiales del S.A.B}

El objeto de este artículo — como venimos señalando- es la torre, porque el conjunto de estudios arqueológicos que realizamos se centraron inicialmente en el análisis estratigráfico de sus fábricas, aunque rápidamente se enfocaron hacia el conocimiento contextual del fenómeno. Las preguntas sin respuesta eran tantas que resultaba casi imposible sustraerse al impulso natural de ensayar nuevas formas de explicación de un proceso complejo. Un impulso que sin embargo no era gratuito, como explicaremos en los últimos epígrafes de este artículo. Una vez conocido el panorama historiográfico - $\mathrm{O}$ al menos una parte relevante del mismo-, a la impresión

${ }^{1}$ A lo largo del texto venimos refiriéndonos al pariente mayor de muy diversas formas — noble, señor, banderizo, etc.-; conviene aclarar que estamos tratando todas las expresiones como sinónimas, aunque somos conscientes que una mayor profundización en la cuestión semántica requeriría un tratamiento diferenciado. general de que prácticamente todas las cuestiones importantes han sido ya tratadas, se opone otra que percibe que no todas las piezas del puzzle se encuentran bien ubicadas, que la de la estructura es precisamente la ausencia más acusada.

Desde nuestro punto de vista, la historiografía medievalista ha tratado a la torre como un elemento casi siempre escenográfico —reduciendo prácticamente todo su significado al de residencia fortificada del pariente mayor-; sólo en escasas ocasiones se ha percibido la necesidad de dedicarle un tratamiento monográfico. Con la argumentación que a continuación se expondrá, no pretendemos convertir la torre banderiza en el elemento central, único y principal protagonista de la crisis bajomedieval en el País Vasco. Sencillamente, trataremos de justificar su trascendencia como elemento infraestructural, faceta en la cual la torre destaca notablemente como instrumento clave en la vertebración del espacio productivo que será familiar al pariente mayor.

El tratamiento recibido por este tipo edificatorio por parte de la Arquitectura y la Historia del Arte ha sido, en contraste, bastante exhaustivo (YRIZAR, 1929; YBARRA BERGé, Garmendia, 1946; Avello, 1991; Jiménez, 1993; Orella Unzué, Estévez, 1996; Palacios, 2001; GonzÁLEZ CEMBellín, 2002), alcanzando algunas obras monográficas dimensiones verdaderamente monumentales. Entre ellas destaca el conocido estudio realizado por M. Portilla hace un cuarto de siglo sobre las torres alavesas, en cuyo capítulo introductorio se encuentra a nuestro juicio una de las mejores síntesis que se pueden leer sobre el tema, a pesar del tiempo discurrido (PORTILla, 1978), y la recentísima obra de J.M. González Cembellín (2005) que únicamente 
pudimos consultar cuando nuestro artículo estaba ya finalizado. Esta obra es, sin duda alguna, la más completa y actualizada de cuantas se han publicado hasta la fecha y constituirá durante tiempo una referencia obligada para cuantos estén interesados en el tema.

Dudamos, en su momento, sobre la conveniencia de modificar o no este artículo (incluso de darlo a conocer) tras la lectura del magnífico estudio de González Cembellín. Finalmente decidimos seguir con la idea inicial, incorporando únicamente algunas reflexiones sobre determinados puntos ya tratados por este autor y que, en nuestra opinión, pueden ser objeto de enfoques complementarios. Seguimos pensando que el detalle de las investigaciones llevadas a cabo desde la perspectiva propia de la Arqueología de la Arquitectura - con la lectura estratigráfica de alzados y el análisis cronotipológico como herramientas operativas - está poniendo de relieve, al menos en las casas-fuertes que hemos analizado, la necesidad de replantear algunos de nuestros conocimientos acerca de estas construcciones. Quede claro, no obstante, que este trabajo no es un review article sobre el estudio de González Cembellín sino, sencillamente, una propuesta analítica sobre las casas-torre a la que se han incorporado algunas consideraciones de última hora (presentadas a modo de cuadros independientes).

En el segundo número de esta revista, se presentaron algunos de los resultados obtenidos durante el estudio arqueológico de la torre de Murga en Álava (GARCía GÓMEZ, 2003: 131-138). En aquella ocasión el esfuerzo se centró en el análisis del edificio en sí, es decir, se trataba de explicar cómo era constructivamente y en cómo se articulaba su espacio al interior. Pues bien, en este artículo trataremos de dar un salto en la escala de nuestra observación, considerando la torre dentro de un sistema construido compuesto por diversos edificios, que definen un contexto fuera del cual la casa-fuerte no tiene razón de ser.

En este sentido, queremos recalcar la necesidad de comprender que - como ya se trató de mostrar en el estudio de Murga - del mismo modo que la torre es un contenedor, un proceso que alberga procesos (FERNÁNDEZ-GALIANO, 1991: 24), a su vez ella misma es un proceso que funciona sistémicamente en unión a otras construcciones/procesos. Ese complejo construido, compuesto por tipos diversos de edificios - cada uno con su funcionalidad característica - conformaría la infraestructura edificada sobre la que se asentaría el sistema de producción controlado por el pariente mayor.

Esta última idea nos parece fundamental. Si bien los historiadores que han profundizado en lo que se conoce como «las bases materiales del poder de los Parientes Mayores» principalmente J.R. Díaz de Durana (1998: 235-260; 2000 : 45-73) y A.F. Dacosta (2002: 43-64; 2003: 95-112)— han aportado datos clave para el conocimiento de las fuentes de renta de los linajes banderizos, sus intereses se han circunscrito al conocimiento de los flujos de la riqueza y en la reflexión sobre el recurso natural explotado en cada caso (bosque, tierras de cereal, seles, etc.), en los casos en que se han preocupado del patrimonio inmueble, éste es considerado sólo en su faceta de bien raíz, como un pasivo, mientras que en las ocasiones en que se considera un edificio como activo —el molino o la iglesia de patronato- su papel queda esquematizado como mero vehículo del proceso de generación de riqueza.

Que esto sea así, en nuestra opinión tiene que ver ante todo con la naturaleza de las fuentes documentales. La atención, en efecto, que en la documentación escrita se presta a los elementos construidos es mínima. Sin embargo, desde un enfoque arqueológico, la torre es memoria de sí misma, una memoria organizada sistémicamente. La información se encuentra acumulada dentro de la fábrica en forma de estratos. Como decíamos recientemente (AZKARATE, LASAGABASTER, e.p.) es con el método estratigráfico con el que podemos luchar contra las zonas de penumbra de la memoria petrificada, contra la apariencia de la homogeneidad absoluta y contra la casi inevitable tentación de considerar a los edificios como modelos congelados en el tiempo. Pero — del mismo modo que la estratificación no es sólo el resultado de la suma de las partes sino que tiene un sentido conjunto, sistémico, que es en definitiva el edificio en sí-, a una escala superior, ese edificio debe ser considerado como una parte más dentro de un sistema construido compuesto por un grupo de edificios que funcionan unitariamente. Así, torre, molino, iglesia de patronato, ferrería, puente, etc., a partir del nexo común que suponen el territorio y las vías de comunicación, constituyeron en la Baja Edad Media una realidad compacta, tan vivida y materialmente reconocible como la propia torre².

2 «El enfoque de sistemas es una manera de pensar en términos de interconexión, relaciones y contexto. Según este enfoque, las propiedades esenciales de un organismo, de una sociedad o de otros sistemas complejos son propiedades del conjunto, que surgen de las interacciones y las relaciones entre las partes. Las propiedades de las partes no son intrínsecas y se pueden entender sólo dentro del contexto del todo más amplio. El pensamiento se concentra no en los componentes básicos sino en los principios básicos de la organización. Es «contextual», lo cual es lo opuesto del pensamiento analítico (...) Mirar el sistema desde una perspectiva científica implica dos tareas básicas: una es la identificación y comprensión de las interrelaciones causales más importantes; los vínculos entre diferentes factores y diferentes escalas originan la posibilidad de que los cambios en un componente del sistema repercutan en otras partes del sistema. La otra tarea es comprender la dinámica del sistema. Además de la estructura de los componentes y vínculos, el análisis de las fuerzas que generan la conducta del sistema es esencial, incluyendo la investigación de cómo diferentes componentes y procesos interactúan funcionalmente para generar respuestas al sistema y propiedades emergentes, cómo el sistema se adapta y se transforma» (GAllopín, G. C.; FUNTOWICZ, S.; O'CONNOR, M.; RAVETZ, J., 2001). 


\section{Cuadro 1}

\section{Perspectiva sistémica vs. visión mecanicista en el estudio de las torres}

Para ayudar a la comprensión de las hipótesis que se proponen en este trabajo, creemos obligado insistir en la necesidad de la búsqueda de nuevos horizontes teóricos. Sendas que muchos de los historiadores que tratan la lucha de bandos o las casas-torre, vienen recorriendo desde hace algunos años —al menos de forma implícita en sus estudios_- pero que aún no parecen suficientemente afianzadas. A nuestro juicio, el bagaje historiográfico y la información documental acumulada es tal, que una mayor recopilación de datos no redundará en la mejora de los conocimientos si no se intensifica el debate en torno a la metodología de las investigaciones que llevamos a cabo. En esta línea, planteamos la utilidad del enfoque sistémico frente a las visiones de tipo mecanicista.

Por distintas razones, la visión de tipo mecanicista ha sido - $-\mathrm{y}$ es - la predominante en los estudios realizados sobre la torre bajomedieval, todos caracterizados principalmente por seguir rígidos esquemas del tipo "causa-efecto». En ellos, la torre es considerada instrumentalmente como la consecuencia de una coyuntura histórica, no se concibe que tenga un papel activo en la reproducción del sistema social o en el modelado del contexto histórico. Este tipo de discurso — profundamente arraigado en la tradición historiográfica vasca- puede tener su origen en la propia naturaleza de la documentación en la que se basa: como sabemos, a pesar de la relativa riqueza de menciones, el fenómeno construido de la torre es considerado sólo de forma marginal en el registro escrito.
No ha sido diferente el tratamiento desde disciplinas como la Arquitectura o la Historia del Arte, pues aunque se han interesado por la calidad monumental de este tipo de edificios - concentrándose en el estudio de sus características estéticas y estilístico/formales-, éstas raramente han considerado la materialidad de la torre como un contenedor de información histórica, por lo que se han remitido al documento escrito como fuente básica, desembocando de nuevo en el esquema "causa-efecto», donde la torre es sólo un producto.

El enfoque sistémico que propugnamos en este artículo, sin rechazar la idea de que la torre es una de las consecuencias de una sociedad militarizada, resalta la retroalimentación - o feedback - como constante que caracteriza la relación entre sociedad y edificio: entendiendo que la torre también actúa como sujeto agente en el modelado del territorio y que, por lo tanto, contribuye en la gestación de un tipo concreto de sociedad militarizada.

Según F. Capra (1998: 57) «en la visión mecanicista, el mundo es una colección de objetos. Éstos por supuesto, interactúan y aquí y allá aparecen relaciones entre ellos, pero estas son secundarias. En la visión sistémica vemos que los objetos en sí mismos son redes de relaciones inmersos en redes mayores. Para el pensador sistémico las relaciones son prioritarias. Las fronteras entre patrones discernibles (“objetos") son secundarias». Hasta mediados del siglo XX, las explicaciones del fenómeno de la lucha de bandos y la erección de las torres con-
Arriba: Esquema de la evolución en la concepción del espacio por parte de la historiografía. (A) Como un objeto; (B) Como soporte; (C) Como vehículo. Abajo: Esquema de visión mecanicista (causa-efecto); Esquema de visión sistémica (retroalimentación)
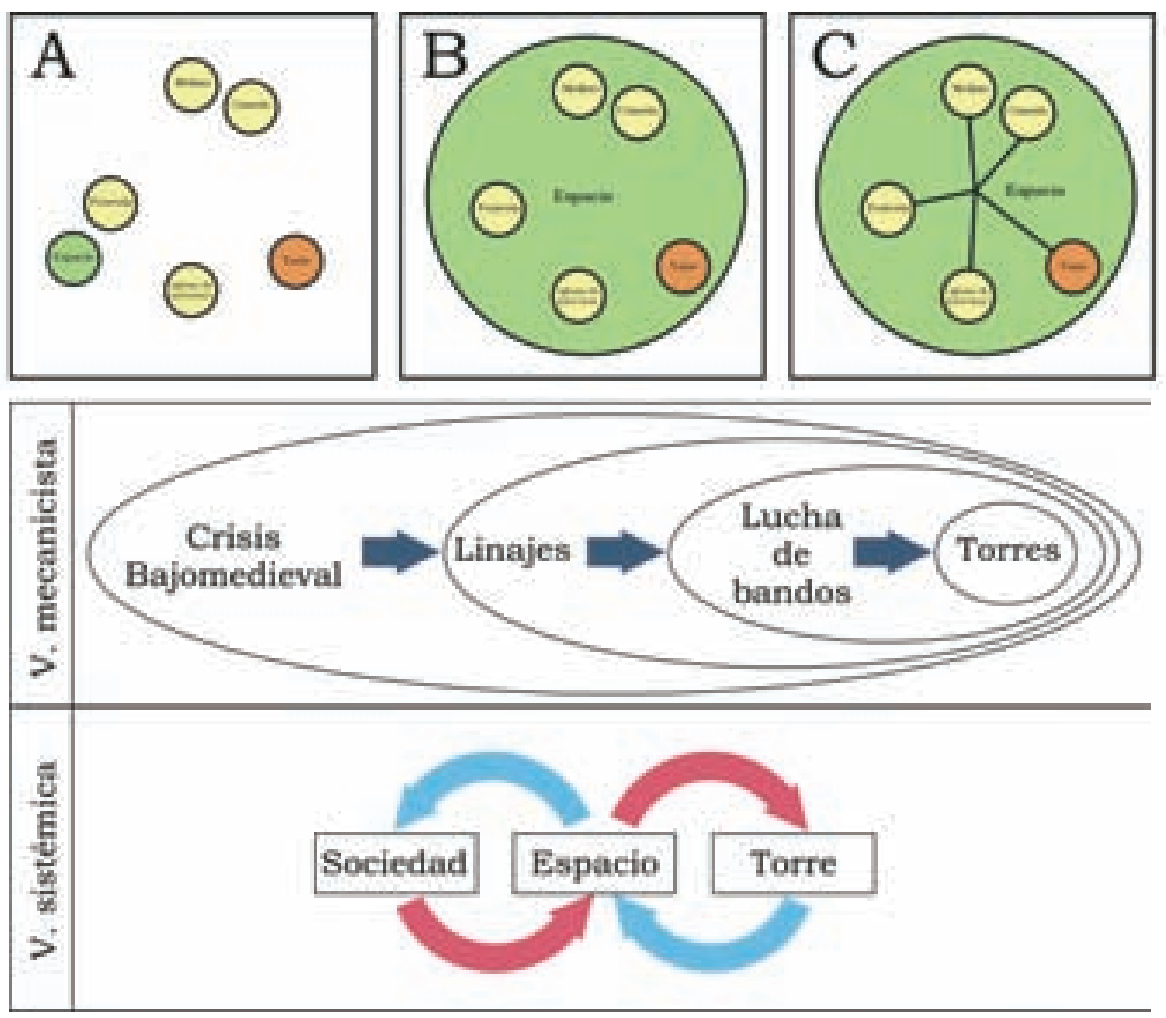
sideraban el territorio —el espacio— como un objeto más de su descripción (A); de entonces a la actualidad, el territorio ha sido considerado, con matices, el soporte del patrimonio inmueble del pariente mayor, y también de las rutas comerciales por las que éste tanto parece interesarse (B). En nuestra opinión, aún no ha sido adecuadamente estudiada su función clave —al menos en lo que se refiere al tema que tratamos-: el territorio como vehículo de relaciones espaciales (C). Si, como señala Capra, las relaciones son prioritarias para el conocimiento de un sistema, para nosotros deberá ser un objetivo prioritario conocer el nexo espacial/territorial, pues sólo en la medida en que seamos capaces de probar que existe efectivamente una co- nexión física de algún tipo, estaremos en disposición de hablar con propiedad de un S.A.B.

Estamos persuadidos de la existencia del S.A.B. Éste, estaría compuesto por la torre donde habita el señor, a la que se sumarían distintas combinaciones de los siguientes elementos: molino, ferrería, iglesia de patronato, puente o portal. Nuestra convicción surge de la hipótesis de que la relación espacial entre los distintos componentes del sistema no se cimienta en la inmediatez del emplazamiento de aquellos con respecto a la torre, sino en la accesibilidad o conectividad potencial a través de la red viaria, independientemente de la cercanía con respecto a la casa-torre del pariente mayor.
Brevemente en las líneas que siguen, y tomando como punto de partida los trabajos ya señalados de Díaz de Durana, rastrearemos algunas de las fuentes de riqueza del $\mathrm{Pa}$ riente Mayor, haciendo especial hincapié en las características de los elementos de la infraestructura construida en que se basan. Más adelante, expondremos la forma en que interactúan los citados elementos al conformar un sistema arquitectónico. No es nuestra pretensión insistir en exceso en la descripción de cada uno de los edificios y su funcionalidad por tratarse de cuestiones sobradamente conocidas. Creemos, sin embargo, que es conveniente destacar algunas características de aquellos, pues constatan su inevitable encadenamiento al resto del sistema.

\subsubsection{El molino}

En 1378, a su muerte, Fernán Pérez de Ayala —uno de los principales Parientes Mayores del solar vasco- hace donación de los bienes inmuebles que posee en el lugar de Quejana para la fundación de un convento de monjas de la Orden de Santo Domingo. Entre el patrimonio donado se encuentran la torre banderiza con su palacio — casa madre del linaje de los Ayala - , algunas heredades y sernas en Arceniega, tierras en Ibaizábal, diversos patronatos sobre iglesias como la de Abecia en Urcabustaiz, y varios molinos en Arceniega, Salmantón, Ibaizábal y Cigoitia (PorTILlA, 1988: 15).

Para el análisis sistémico que proponemos, este acto testamentario resulta especialmente interesante por dos cuestiones. En primer lugar, porque ofrece una imagen prototípica, con algunos de los bienes inmuebles que caracterizan distintivamente el paisaje del pariente mayor. En segundo lugar, porque expresa cómo en la mente de aquel señor existe realmente una consciencia sistémica del patrimonio inmobiliario poseído. Por ello, para la fundación monástica no se considera suficiente la segregación de un único inmueble - que podría ser la torre - sino que se ve como lógica y natural la donación de un conjunto compacto de bienes raíces y edificios cuya explotación garantizará los recursos económicos sufi- cientes para el mantenimiento de la congregación y del recinto que la acoge. No se traspasan por lo tanto elementos arquitectónicos individualmente; lo que se dona es un paquete completo, cuya concepción unitaria no se fija en el instante del acto de donación sino antes, durante el proceso de formación del patrimonio familiar a lo largo del tiempo.

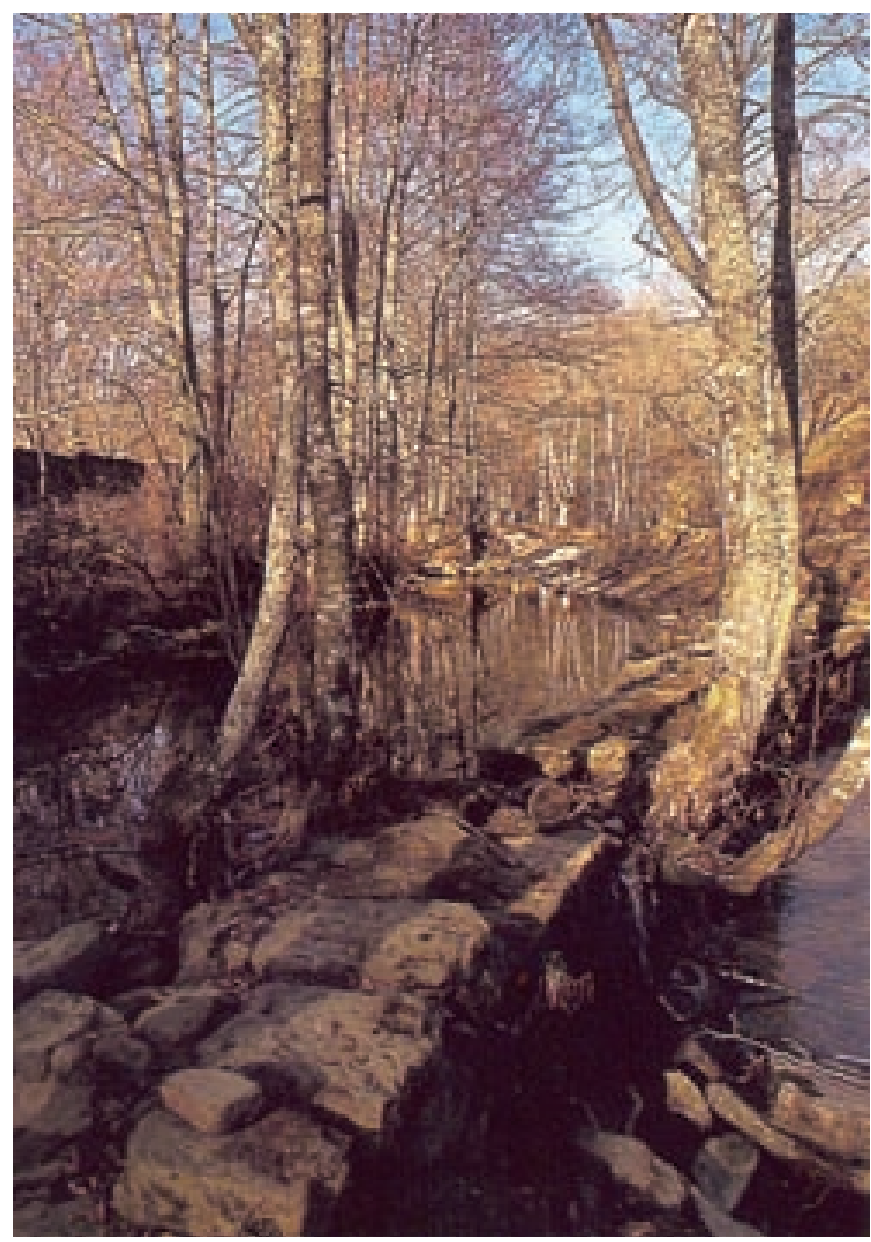

Dique del molino de Murua (Zigoitia, Álava). Aunque se trata de un ejemplar del siglo xvill, la sencillez del murete de piedra con apenas resalte, nos da una idea de las reducidas dimensiones de las explotaciones medievales (Foto: Santiago Yaniz Aramendia) 
Centrémonos por ahora en aquellos molinos de los sitios de Arceniega, Salmantón y los otros: La ubicación de éstos en la mayor parte de los casos coincide con el entorno próximo de la torre banderiza que dominaban los Ayala en Quejana —un radio de menos de $8 \mathrm{~km}$ - Pero el de la inmediatez espacial no era requisito imprescindible pues, como comprobamos, el molino de Cigoitia se encontraba $32 \mathrm{~km}$ distante ${ }^{3}$. Efectivamente, las posesiones del pariente mayor podían emplazarse inmediatamente junto a su torre, pero esto no sucedía en todos los casos. Como explicaremos más adelante, si bien podía considerarse una ventaja añadida contar con la proximidad del edificio fuerte de la familia, esta no era una conditio sine que non para la erección de un molino.

El control de un molino desde la fortaleza señorial era clave, porque además permitía una importante cuota de dominio sobre un cauce fluvial determinado. Al respecto, podemos traer a colación el caso de un molino situado en las cercanías de Vitoria, en Abechuco. Citaremos directamente nuestra fuente: "De las propiedades de los Iruñas en Abechuco habla la orden del consejo de Castilla y León dirigida, con emplazamiento, a dicho Don Andrés Martinez y a su hijo Don Martín en 1493, disponiendo que consintiesen a Don Diego Martínez de Álava pasar el agua de la presa de un molino que los Iruñas tenían en Abechuco a otro molino que Don Diego habia edificado aguas debajo de dicha presa" (Portilla, 1978: 985). El de los Iruña era uno de los principales linajes banderizos en la Llanada Alavesa, el cual poseía un molino en el cauce del Zadorra, cuya presa retenía el caudal, en modo que las ruedas situadas aguas abajo no podían aprovecharse del mismo. Aquí encontramos ejemplificado uno de los modos de control del territorio de que disponía el pariente mayor: la gestión privativa mediante el represado del recurso hídrico. «En el monopolio de la energía hidráulica se asentarán las bases del molino feudal», determinaba R. Martí (1988: 171).

La posibilidad de administrar el proceso de la molienda mediante una explotación en propiedad, convertía al señor no sólo en el principal beneficiario de los pagos por el usufructo de aquella sino también - y sobre todo- en un privilegiado gestor del ciclo productivo cerealista. Este resorte de poder sobre la producción le permitía marcar los ritmos y flujos que influirían en aspectos fundamentales de la economía bajomedieval, como la cantidad de cereal destinada a la panificación para el alimento humano, la cantidad

\footnotetext{
3 Como se explica en uno de los cuadros adjuntos, en nuestra opinión no resulta acertado pensar que una mayor distancia física supone la ausencia de relaciones espaciales entre la torre y el resto de elementos del S.A.B.
}

reservada como simiente para próximas cosechas o sencillamente - en un contexto en el que lo habitual es el pago en especie- el reforzamiento del dominio fiscal.

\subsubsection{La ferrería}

Como iremos observando, la forma en que el pariente mayor controla el territorio no se distingue por la demarcación de un espacio más o menos extenso, definido por un limite concreto por todos conocido: no es el control de una parcela extensa del soporte espacial lo que otorga el poder efectivo al señor - quedando todo proceso productivo en él contenido bajo su dominio indiscutible- sino que lo obtiene mediante un control de ciertos puntos neurálgicos dispersos en el medio geográfico. Esta precisión nos parece importante, porque a la postre nos sitúa ante una evidencia sustancial: es el S.A.B. uno de los nexos entre sociedad y territorio más evidentes o, dicho de otro modo, uno de los instrumentos que permiten la organización de éste último.

En los nodos claves del territorio, siempre según las posibilidades tecnológicas del momento, acaba apareciendo un tipo edificado que se especializa en la explotación de los recursos que allí confluyen. Estas infraestructuras actúan como un diafragma, regulando los inputs y los outputs propios de cada ciclo productivo.

La ferrería, como el molino - en la medida en que se basan en mecanismos motores análogos que necesitan también del represado de aguas-, servía también como gestor de la energía hidráulica disponible. Ello nos permite hacer una observación que creemos digna de ser tenida en cuenta, pues podemos percibir cómo al compartir el mismo recurso, ambos elementos infraestructurales son dependientes entre sí. Una alteración que afectase a uno de los ciclos productivos más directamente implicados — sobre todo los del cereal y del hierro- repercutiría considerablemente en los otros.

Desde nuestro punto de vista, esta íntima conexión de los distintos ciclos, pudo ser uno de los factores que aconsejara la especialización productiva de la vertiente cantábrica del País Vasco en la actividad ferrona, mientras que la vertiente mediterránea se concentraba en la producción cerealista. Incluso, creemos posible que dentro de los intereses geoestratégicos del pariente mayor, la necesidad de armonizar la actividad ferrería/molino, primara sobre otros condicionantes naturales aparentemente más evidentes - disponibilidad de una mayor masa boscosa, mayor caudal de los cursos fluviales-. Veamos algún dato documental:

"Yo he sido informado y sé de cierto que a causa de la dicha herrería y del procedimiento de ella los montes altos de la dha hermandad y Sierra de Gorveia se destruian y de tal manera y en tanta manera que se destruía el pasto y el pan y la 


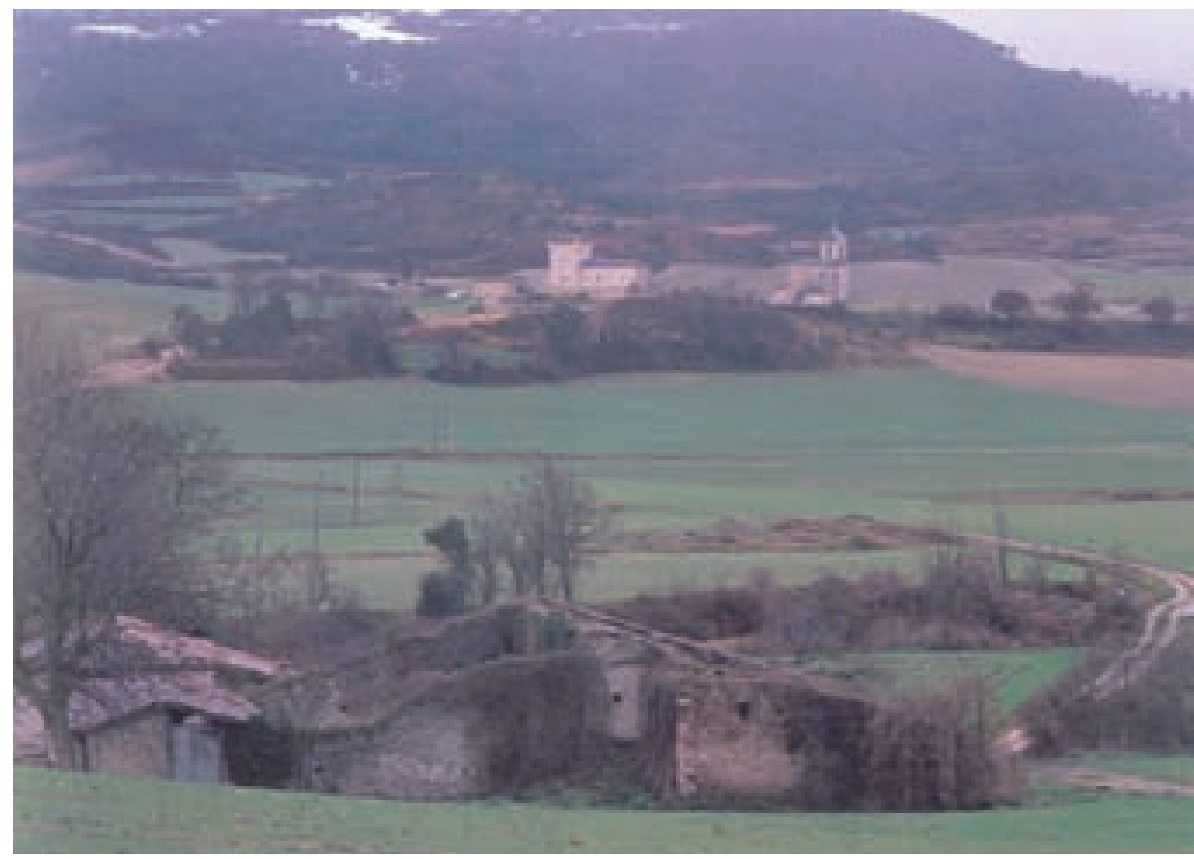

Villanañe (Álava). En primer término, la ferrería propiedad de los señores de la Torre de los Varona, la cual se encuentra al fondo de la imagen junto la iglesia de su patronato (Foto: Santiago Yaniz Aramendia) grana de los dichos montes, y a causa de esto se despoblara la tierra por no tener con que surtirse sus ganados asi de labranza como de cría y porque a mi me es más útil y provechoso sostener la dha población de los dhos lugares que sois mis vasallos, que no que se me despoble la dha tierra, y es más provechoso para mi casa y estado tener poblada mi tierra y vasallos de que más me sirvo y me pagaba alcabalas y otros derechos y tributos» (IbaÑEz, Torrecilla, Zabala, 1992: 143). Este texto se extrae de la escritura de venta de la ferrería de Almadian (Cigoitia) que otorgó Diego Hurtado de Mendoza en 1516, quien no fue él único pariente mayor en preferir la eliminación de alguna de las explotaciones ferronas en pie en tierras alavesas aún en el siglo XV. De modo análogo actuaría Martín de Abendaño cuando en esas mismas fechas decidió el derribo de su ferrería en Villarreal.

Esta reconversión tardía del sector se insertaba en una dinámica más amplia que podemos remontar a los primeros años del siglo XIV, siendo uno de sus hitos imprescindibles la orden dictada en 1332 por Alfonso XI, prohibiendo expresamente la construcción de ferrerías en el espacio alavés. Como consecuencia, el territorio donde se ubicaron las primeras explotaciones documentadas del ámbito vasco - siglo IX- perdió su primacía en el sector (GARCÍA DE CORTÁZAR, MONTERO: 271-273).

Pasemos ahora a tratar otro aspecto destacable de este tipo de explotación. El ciclo productivo del hierro ha estado siempre determinado por la elevada temperatura necesaria para que tuviera lugar la fusión, pero sabemos que en épocas preindustriales ese nivel de calor no era técnicamen- te alcanzable, por lo que el tratamiento para la transformación del mineral consistía en una sucesión de complicados procesos que permitían alcanzar unos niveles de pureza aceptables (MANNONI, GIANNICHEDDA, 2003: 111-114).

La ferrería era un gran consumidor de madera, por encima de la construcción o de la industria naval. Esta demanda alteraba numerosos ciclos productivos que compartían la explotación del recurso.

En una visión no-sistémica de la producción ferrona, la factoría sólo es elemento dependiente en la relación madera/ferrería, un esquema donde la escasez de materia prima determinaría la pervivencia o no de este tipo de explotación: pero la relación entre los elementos de un sistema rara vez es unidireccional. Desde nuestra perspectiva, una vez edificada una ferrería en un punto favorable del medio, la suerte de ésta no se encuentra únicamente determinada por la evolución natural de los recursos boscosos de su entorno, sino que su existencia produce transformaciones en el tejido socio-económico que tienden, a su vez, a garantizar su subsistencia: el edificio debe ser entendido no sólo como un producto del sistema, pues genera comportamientos y coadyuva estrategias de control que remodelan constantemente el propio sistema. El Fuero de Ferrerías de Vizcaya, en 1440, protegía todo este sistema de explotación, amparando el transporte del material antes y después de su elaboración, castigando la quema de los montes o concediendo a los ferrones — esto es clave - la posibilidad de utilizar los bosques comunales (GARCía DE CORTÁzAR, MONTERO, 1999: 276-277). 


\subsubsection{La iglesia de patronato}

Sin rueda ni mecanismo alguno que nos permita identificarla como una factoría más en poder del pariente mayor, la iglesia de patronato fue también un elemento característico de la infraestructura arquitectónica sobre la que se basaba el modo de producción banderizo. Como resulta evidente, algunas de sus especificidades lo convertían en una construcción del todo particular, pero su lógica funcional dentro del sistema nos muestra un tipo edificado con gran parecido a los anteriormente descritos.

Una de las similitudes se aprecia en la forma de obtener el derecho de patronato. Según se disponía en las Siete Partidas de Alfonso X el Sabio: «...este derecho gana home por tres cosas: la una por el suelo que da en que se faga la iglesia: la segunda por facerla: la tercera por el heredamiento quel da que llaman dote...» (LARREA, 2000: 12). Como se colige de esta normativa, salvo que el patronato fuera heredado - pues podía ser legado como cualquier otro bien patrimonial de un linaje- su consecución estaba directamente relacionada con la dotación material necesaria para la elevación del edificio sagrado y su mantenimiento.

En tanto que responsable del mantenimiento material del culto en el templo apadrinado, el señor tenía derecho a quedarse con parte de los ingresos decimales, en una porción que solía oscilar entre la mitad y los tres cuartos del total de la imposición. Este tipo de renta que - como en el caso del molino- se percibía en grano, permitía al pariente mayor disponer de un importante stock frumentario almacenado, del cual podía servirse en diverso modo: racio- nándolo en beneficio propio en épocas de carestía, reutilizándolo en la siembra de años sucesivos, optando por la venta, o bien acumulando para la especulación. Como señala Díaz de Durana, en algunas ocasiones los ingresos anuales que podía reportar este método impositivo superaban el $50 \%$ del total embolsado por el pariente mayor de turno (2000: 63).

Hechas estas observaciones, debemos advertir sobre la extrema complejidad del reparto de los bienes decimales, problemática que responde a la propia e intrincada organización de las diferentes iglesias de patronato. La mínima semblanza que hemos realizado nos permite esbozar una idea aproximada sobre la importancia de esta infraestructura como mecanismo para la dominación en manos del señor: por un lado — de nuevo- permitía un control directo de los ritmos y volumen del ciclo productivo del cereal; por otro facilitaba un cierto control ideológico, pues en la mayoría de las ocasiones el párroco había sido escogido por afinidad al pariente mayor.

Conviene reseñar, por otro lado, que la materialidad del inmueble no siempre recibía el tratamiento adecuado. Generalmente los edificios no contaban con el mantenimiento previsto, encontrándose muchos de ellos en un estado próximo al abandono, o a duras penas en pie gracias a las contribuciones que en forma de limosna hacían los feligreses. «Es difícil precisar qué razones impulsaron a la nobleza a mantener en estado deplorable los templos y a la mayoría de sus clérigos como una masa de desheredados» (CATAlÁN, 2000: 43-44).

En primer plano, la ermita de San Antonio, patronato de los señores de la Torre de Martiartu

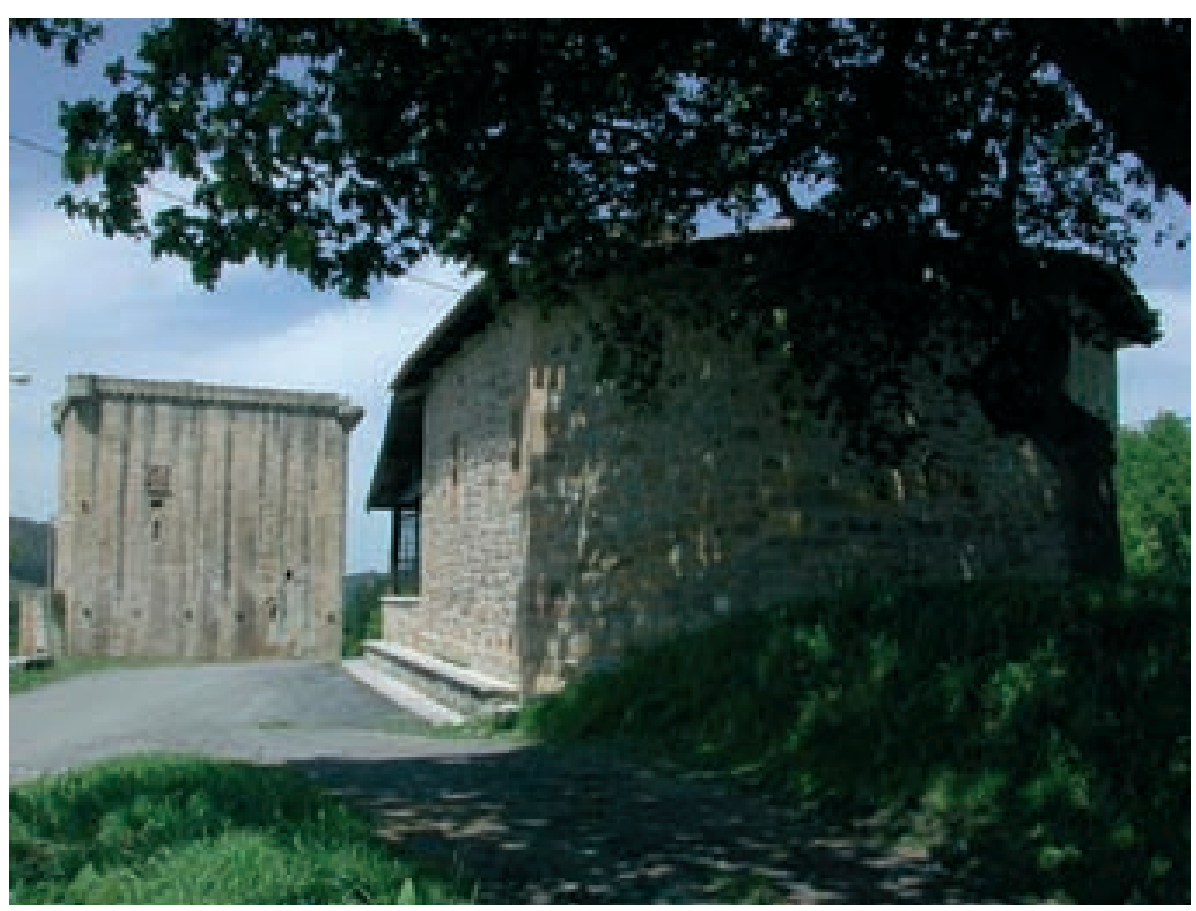




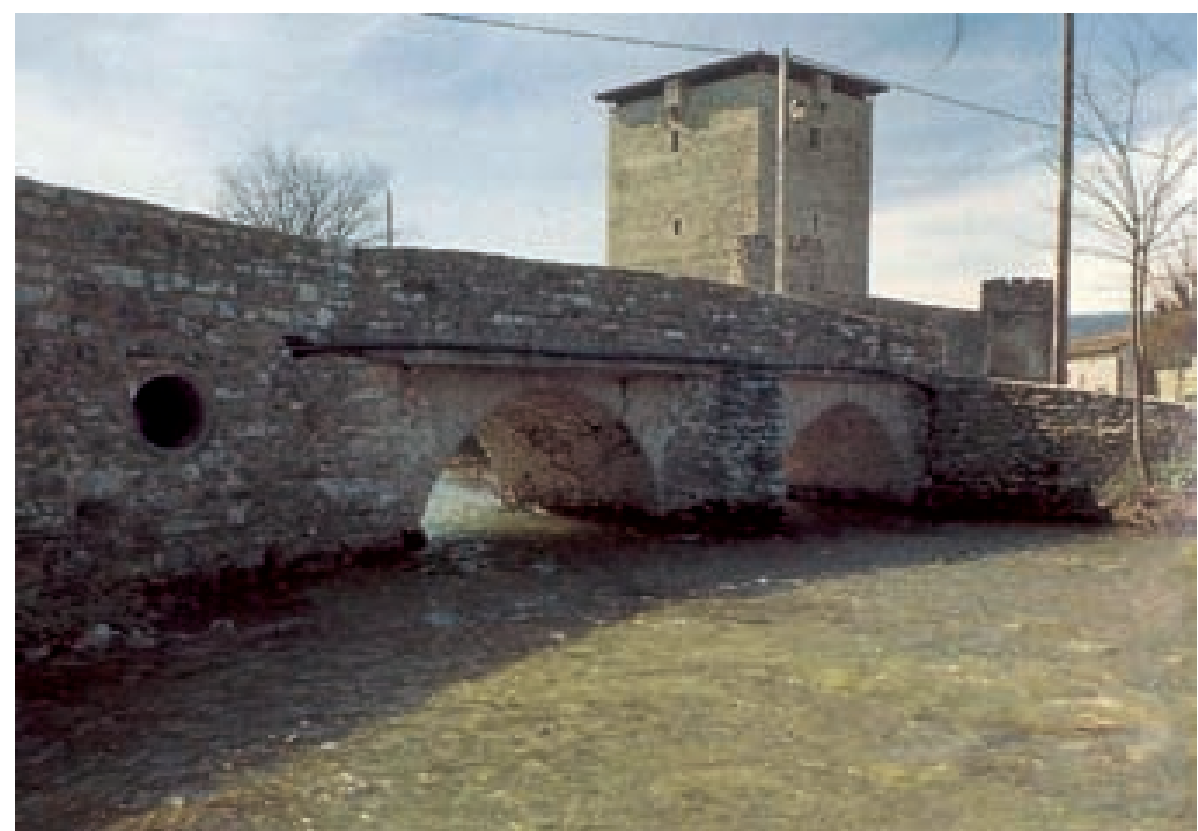

Torre de Mendoza (Mendoza, Álava). Aunque la mayor parte de los puentes medievales han desaparecido, aún se puede observar cómo muchas torres se sitúan junto al cruce de los cauces fluviales (Foto: A. Azkarate, V. Palacios y J. Pérez)
Un cuidado especial debía recibir, sin embargo, una parte clave de la estructura del inmueble: el almacén. Dejando a un lado los aspectos puramente religiosos, era la estructura que daba razón de ser a la iglesia en el contexto de la explotación de los recursos del territorio. Silos, paneras y hórreos fueron las diferentes soluciones constructivas adoptadas, el lugar donde depositar las rentas decimales colectadas. Construidas en madera o piedra, eran edificaciones anejas al templo que constaban de un soporte sobreelevado que proporcionaba un efectivo aislamiento de la humedad del suelo y de los roedores.

\subsubsection{Puentes, portales, pasos y torres como "puertas lógicas» ${ }^{4}$}

Habitualmente consideramos la torre o casa-fuerte como un elemento funcional por sí mismo; después de todo, no sería mucho más que la vivienda fortificada del señor, la cual —además de protección- le facilitaría el dominio sobre el medio circundante. Sin embargo, como iremos viendo, la torre era sobre todo el centro de la coordinación productiva del linaje (DACOSTA, 2003: 305) y necesitaba del control efectivo de la infraestructura viaria para ejercer su potestad. Para desarrollar este rol, raramente se bastaba por sí misma, necesitaba de otro elemento construido aledaño: el puente o el portal. Estructuras que, por su íntima relación

\footnotetext{
4 Tomamos este neologismo procedente del mundo de la Electrónica, pues encontramos una gran similitud entre el funcionamiento de este tipo de dispositivos electrónicos y la forma en que la torre controla pasos claves de las rutas comerciales.
}

con la propia torre, deberían ser consideradas casi como una parte más de su fábrica, o al menos con una funcionalidad indisociable. Sin embargo, la historiografía en raras ocasiones se ocupa de ellas. Puentes y portales son considerados injustamente como elementos contingentes, cuando la realidad indica que — probablemente — son ellos los que hacen que la empresa de construcción de estas fortalezas sea algo rentable.

Como señalamos al inicio, el soporte geográfico no es homogéneo. De hecho, la heterogeneidad de la orografía - expresada en cursos fluviales, valles, cordilleras, etc.- es el primer factor determinante en la configuración de las comunicaciones y de los flujos comerciales. Desde siempre, el hombre se ha adaptado a ese patrón geográfico tanto para decidir el establecimiento de sus asentamientos como para establecer las rutas practicables para circular de un lado a otro (González Minués, Hoz DíAz de AldA, 1991: 16). A la par de esos recorridos que se afianzaban, fueron evolucionando diferentes formas de control de la infraestructura viaria. En el contexto bajomedieval que nos ocupa, la torre podría considerarse como uno de los modos más extendidos de regulación de las comunicaciones.

La forma básica de este tipo de control consistió en la colocación de puntos fuertes en aquellos pasos — vados o puertos de montaña - que, dotados innatamente por la naturaleza, eran corredores de pasaje obligado. Sin embargo, la construcción de cierto tipo de infraestructuras viarias - como los puentes - tendió a modificar, potenciar y condicionar la movilidad, estimulando el tráfico de ciertos trazados viarios que de otro modo habrían quedado relegados a un segundo o 
Torre de los Guevara (Vitoria-Gasteiz). Situada junto al portal de la Calle Cuchillería - cuya entrada vemos a la derecha de la imagenaún se encontraba en pie a finales del siglo XIX (Foto: Archivo Municipal de Vitoria-Gasteiz)

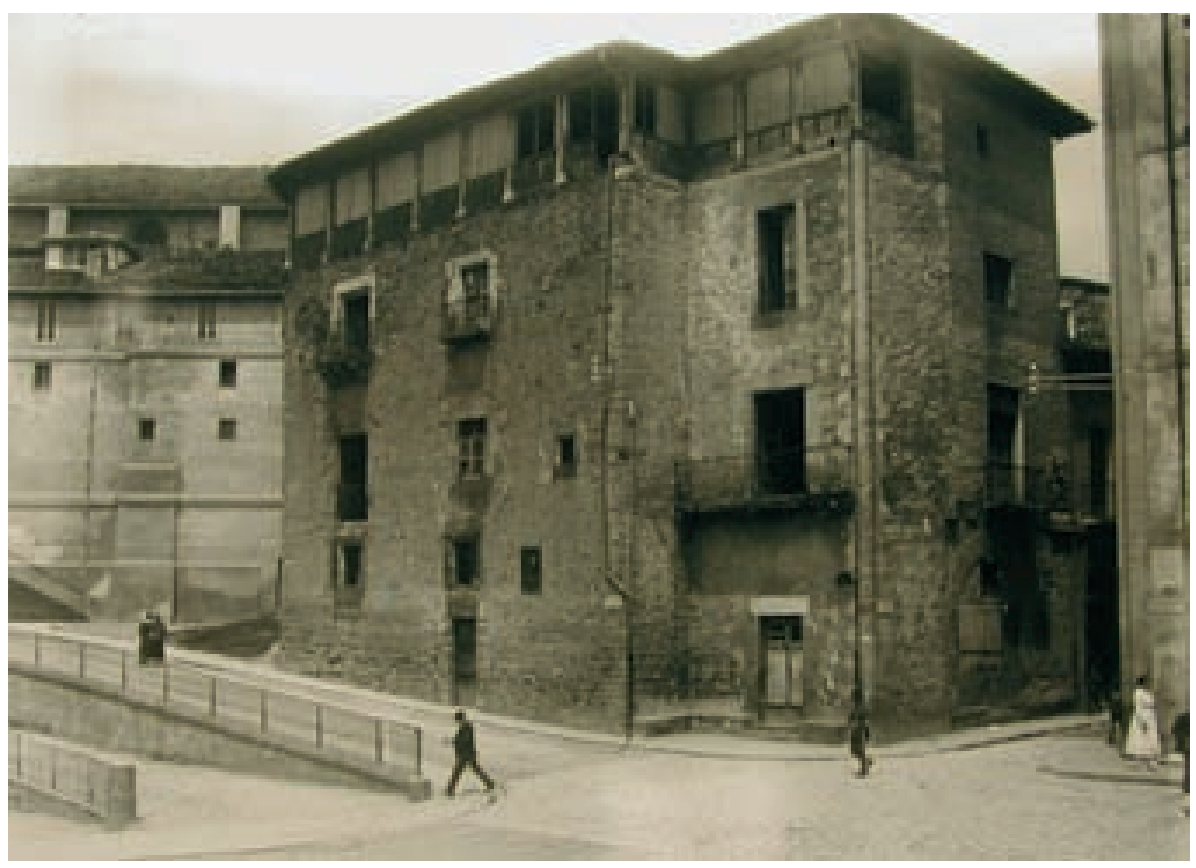

tercer plano. El puente - precisamente porque facilitaba la superación del obstáculo fluvial - se convertía en un punto focal para la circulación. La existencia de uno de estos hitos, producía un efecto de convergencia por el cual los diferentes tránsitos tendían a arracimarse: el control del puente era por lo tanto una de las alternativas más eficaces para alcanzar un dominio específico sobre el flujo comercial.

Sin duda la reparación de la red viaria era una cuestión de primer orden, tanto para la corona - recordemos a Alfonso X en sus Partidas reconociendo esta tarea de mantenimiento como una obligación de la monarquía-, como para los concejos de las diferentes poblaciones - que eran a la postre quienes soportaban el grueso de los costes-. El esfuerzo económico que requiere la manutención de las infraestructuras sería el argumento que justificaba el cobro de tasas. De nuevo se percibe la presencia del noble que directa, o indirectamente - haciendo uso de su influencia sobre los concejos-, trata de obtener un beneficio personal: "Mandamos que non se lleven ni cojan nin puedan llevar nin coger (...) el pontaje que se coge en Miranda por el conde de Salinas, salvo lo que antiguamente se acostumbro a coger e cogia por la dicha villa para el reparo de la puente, que es a blanca vieja por la bestia cargada e a media blanca por la vazia (...); e que los vezinos e moradores de la dicha villa sean syempre tenidos e obligados a reparar e thener todavía reparada la dicha puente, syn que se aya de echar nin coger otra ynpusiçion alguna para ello" (Mandamiento de los Reyes Católicos, dado en Vitoria en 1486: GonZÁLEZ MíngUEZ, Hoz DíAz de Alda, 1991: 131).
Los parientes mayores emplazaron la mayor parte de sus edificaciones fortificadas directamente sobre aquellos puntos donde un puente permitía cruzar un río. Esto les permitía dominarlo y regular directamente la imposición de rentas por su utilización, amén de otros abusos constantemente denunciados por viajeros y comerciantes: " $A l$ gunos vezinos de Bitoria se me enbiaron querellar e dizen que algunos del dicho lugar que andan caminos que vien de Castiella a Nauarra e a otras partes con sus mercadorias (...) que salen a ellos omes poderosos de y de la tierra e otros omes que les toman e prenden forçadament lo que les fallan, contra su voluntad, deziendo que les den de cada bestia e azemila, çiertos dineros de guia que dizen que han de aver» (Orden de Pedro I, dada en Sevilla en 1358: GonzÁlez Mínguez, Hoz DíAz DE ALDA, 1991: 41).

Algo similar sucedía con el pago de portazgos en el momento de atravesar el cinturón amurallado de una villa. De hecho, desde un punto de vista configuracional respecto del sistema considerado, el control por obturación $n^{5}$ que realizan las torres cuando se colocan junto a un puente no es distinto del que ejercen cuando se sitúan junto a los portales de las murallas; en ambos casos se crean sendas puertas lógicas que gestionan conmutativamente la circulación de la sabia comercial.

Los derechos por portazgo son inseparables del ámbito urbano $y$, en un principio, al igual que en el caso del

\footnotetext{
$5 \mathrm{Al}$ respecto, ver cuadro «Espacio hodológico y control por obturación».
} 


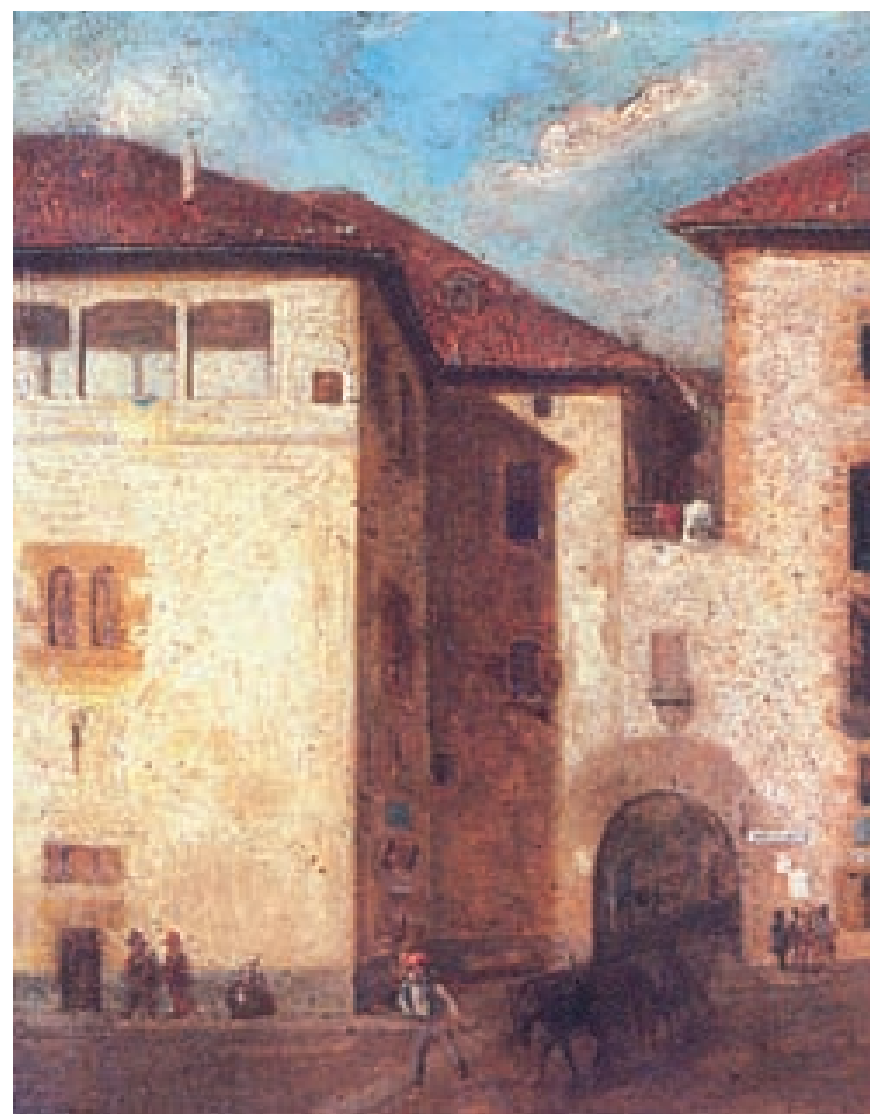

Estado de la Torre de los Abendaño (Vitoria-Gasteiz) en el siglo xIx. Se trata del edificio situado a la izquierda de la imagen, el cual controlaba el acceso a la ciudad por el portal de la Calle Herrería («Vista del arco de Herrería» de Juan Ángel Sáez, cuadro propiedad del Ayuntamiento de Vitoria-Gasteiz)

pontazgo, son prerrogativa real aunque en la práctica se delegasen en potentados locales. En este sentido, son conocidos numerosos casos, como el del portazgo de la fruta que entraba en Vitoria por el Portal de Arriaga que era privativo del linaje de los Mendoza en el siglo XIV (PorTilla, 1978: 1071). La creación de uno de estos puestos pretendía, según se indica en las Partidas «mejorar algún lugar que esta muy pobre, e por ser el camino mas seguro o por otra razon semejante destas» y se fundamentaba jurídicamente en la protección que el rey otorgaba a cambio de la imposición.

Ciertamente, allí donde se establecía uno de estos puntos de control, la actividad comercial aumentaba muy considerablemente debido a que también en ellos debían converger obligatoriamente mercaderes y mercancías (GONZÁLEZ MínguEZ, 1989: 146). Pronto se convirtieron en uno de los atractivos característicos del ámbito urbano que, junto al propio mercado, captaron la atención del pariente mayor.

\subsubsection{La torre, producto reproductor}

En fin, molino, ferrería, iglesia de patronato, puente y portal, conforman junto a la torre, la infraestructura básica de la que se sirve el pariente mayor para el control del territorio, dentro de una modalidad que hemos denominado control por obturación. Cada uno de estos elementos cuenta con un principio activo esencial, que le asigna un papel concreto dentro del esquema de explotación de los recursos naturales, pero los citados elementos suponen poco por sí mismos, son segmentos interdependientes de una realidad que adquiere su verdadera dimensión sólo cuando se consideran en conjunto. Dando un salto de escala, la imbricación estructural de cada una de estas construcciones genera una realidad cualitativamente más valiosa que no se puede entender como la mera adición de las partes: emerge el S.A.B.

De hecho, la aparición de un tipo como la torre se produce cuando el aludido sistema arquitectónico lleva ya algún tiempo evolucionando sobre el territorio, a la par que en el contexto sociopolítico se va afianzando la figura del pariente mayor, personaje destacado de la comunidad que trata de dominar unas infraestructuras que — de forma visiblemente eficaz- facilitan la obtención de un beneficio por la explotación del territorio.

Las fortalezas que hasta el siglo XIII habían escogido lo alto de los cerros para afianzar sus fábricas pierden importancia con respecto a aquellas que, desde entonces, comienzan a situarse en el fondo de los valles, junto a los cursos fluviales. Ambos tipos de estructuras fortificadas convivirán sin embargo a lo largo de toda la Baja Edad Media; las primeras representando el poder real, y las segundas como expresión del poder emergente de la nobleza local. Una duplicidad funcional que a fin de cuentas recaía en las mismas manos, pues era bastante habitual que el señor de una de aquellas torres situadas en las zonas bajas detentase el cargo de alcaide o similar en algún castillo adscrito a la corona: como es el caso de Pedro Ladrón de Guevara, alcaide del castillo de Ausa (LEMA PUEYO et al., 2000: 117). A diferencia de las fortalezas en altura que controlaban — por así decir- en la distancia (GARCíA CAMINO, 2002: 265-269), las torres se "pegaban» al camino para dominar las rutas comerciales desde «dentro».

Sintetizamos a continuación algunos datos cronológicos que pueden ser ilustrativos a la hora de comprender la emergencia del S.A.B. en relación a cada uno de sus componentes caracterizados por un proceso evolutivo singular:

a) Iglesia de patronato: El origen del patronato laico de iglesias, puede en algunos casos remontarse al siglo XI, si bien será más patente en los siglos XIV y XV su concentración en manos de destacados linajes (LARREA, 2000: 14).

b) Puentes, portales y caminos: La infraestructura viaria se robustece y densifica a partir del despegue comercial posterior a la crisis, durante el siglo XV. No obstante, no se 
puede dejar de observar cómo el intercambio de lana castellana había potenciado una gran actividad mercantil que implicó — desde el siglo XIII — una reorientación de las rutas principales, prevaleciendo desde entonces las vías mercantiles con eje N-S (PorTilla, 1978: 20).

c) Torre: Las torres banderizas más antiguas se pueden remontar a los primeros años del siglo XIII, si bien la gran mayoría de ellas se edificaron a lo largo de los siglos XIV y XV (PORTILLA, 1978: 77).

d) Molino: En el caso del molino hidráulico, aunque existen menciones ya en el siglo IX, la documentación parece retrasar las trazas del monopolio señorial sobre la molienda hasta el siglo XIV (MARTín, 2002: 19).

e) Ferrería: Las primeras menciones de ferrerías se remontan también al siglo IX, pero los investigadores consideran arriesgado hablar de ferrerías hidráulicas en nuestro ámbito con anterioridad al siglo XIV (IBÁÑEZ, TORRECILLA, Zabala, 1992: 138-140; DíEZ de SALAZAR, 1983: 65-66).

Evidentemente, el proceso de convergencia de los diferentes tipos constructivos encierra una complejidad mucho mayor que la asumible en un esquema sintético como éste. Lo habitual es que cada uno de los elementos secuenciados vaya evolucionando de forma paralela —en una dialéctica permanente- hasta que ciertos vínculos se refuerzan lo suficiente como para cristalizar en un mismo cuerpo funcional como el S.A.B.

\section{Una hipótesis sobre los orígenes: el endoparasitismo de los siglos XIII-XIV}

Con bastante anterioridad al desencadenamiento de la llamada crisis bajomedieval cristaliza dentro del sistema feudal el germen de lo que será el S.A.B. Entonces, si las fábricas de las primeras torres que se aproximan al fondo de los valles se remontan a principios del siglo XIII, ¿cómo se explica que exista un desfase de casi una centuria con respecto a la citada depresión del XIV?

Ante una cuestión con tantas implicaciones historiográficas, la necesidad de realizar nuevos estudios arqueológicos sobre este tipo construido se hace imperiosa, pues las dataciones existentes — basadas en criterios estilísticos y formales - requieren una confirmación. No obstante, admitiendo los datos conocidos, debemos preguntarnos acerca de la razón de esa "prematura» aparición de las torres, un hecho no coyuntural, que debería ser adecuadamente encuadrado dentro de las dinámicas propias del sistema feudal. Trataremos de sintetizar nuestra hipótesis en unas pocas frases.

Conocido es que el siglo XIII — sobre todo en su primera mitad- sigue disfrutando del florecimiento económico general: la expansión agrícola aún no ha alcanzado su techo de crecimiento, el pulso del comercio se mantiene pujante y el fenómeno urbano continúa su avance. El sistema se muestra aún pletórico y, sin embargo, la aparición de la torre en este contexto no debemos considerarla una sorpresa. Y. Barel, refiriéndose al fenómeno urbano, dio con una explicación que, en nuestra opinión, podría tener su analogía en la aparición del S.A.B. Dice así: «El sistema no es imaginado antes de ser creado. Emerge clandestinamente en el seno de lo que en este caso es el régimen feudal. Es, si se quiere, un aspecto de la reproducción de este sistema-receptor, una manifestación del hecho de que un sistema que se reproduce, reproduce, al mismo tiempo, algo diferente de sí mismo" (1981: 484-485). Para nosotros, el sistema-receptor — vale decir el sistema feudal— generó en su seno diferentes alternativas de sí mismo. En el ámbito vasco, una de ellas será evidentemente el sistema urbano y otra —que se enmarcará en la Baja Edad Media - será el sistema arquitectónico banderizo.

En su génesis ese sistema arquitectónico se define de forma muy básica. Su primitiva configuración trata de aprovecharse de las fuentes de riqueza más evidentes: por un lado el excedente campesino captado por las organizaciones parroquiales y por otro el comercio.

Durante los siglos XI y XII —algo más tarde según las zonas- el diezmo se generaliza como una prestación obligatoria (LOPEZ AlSinA, 2002: 453-455). A partir de ese momento, los llamados «monasterios» empiezan a convertirse en objetivo del grupo señorial — sobre todo aquellos situados en los núcleos poblados de mayor tamaño, cuya economía contaba con una mayor fortaleza y estaban mejor conectados con las redes de comercio por encontrarse enclavados en espacios de baja cota- Precisamente en Bizkaia, se aprecia un proceso en el cual los feudales surgidos del propio período expansivo juegan un papel protagonista en la reorganización y concentración parroquial. "A mediados del siglo XI esta aristocracia local había iniciado ya el asalto sistemático a las iglesias» (GARCía CAMINO, 2002: 355).

La pujanza del comercio fue otro de los factores que atrajo la mirada de los señores hacia las principales vías de comunicación - pensemos fundamentalmente en el comercio de la lana castellana-. El fortalecimiento del sistema urbano obligó a la elaboración de nuevas estrategias de control del flujo comercial, la nobleza rural no estaba dispuesta a convertirse en mera espectadora del intercambio entre las villas. Se hacía necesario un dominio intensivo del camino: la táctica más eficaz fue la privatización de los pasos clave de las vías de comunicación.

$\mathrm{Al}$ mismo tiempo, en torno a los caminos aumentaba el bandidaje. Una actividad — generalizada en la segunda mitad de este siglo XIII - que aportaba importantes ingresos a las diferentes parentelas, amén de acrecentar su peso 
geoestratégico y político. Obsérvese, por ejemplo, cómo el bandidaje fronterizo constatable en esas fechas en la franja oriental de Guipúzcoa (FernándeZ de LaRREA, 2000: 23) se vertebraba en torno a una de las principales rutas comerciales que atravesaba el territorio desde Irún hasta el túnel de San Adrián. Esta práctica hubiera sido difícilmente sostenible sin la paulatina creación de una red de bases operativas enclavadas en puntos neurálgicos del territorio.

El S.A.B. estará compuesto originalmente por una serie de explotaciones heredadas de la pretérita configuración del dominio señorial, por una o más iglesias de patronato asimilado, y por una torre que — situada junto a esos puntos neurálgicos de la red viaria - controlara las rutas comerciales por obturación.

Como se puede comprobar, se trata de un sistema de apropiación económica que se despreocupa de participar en la creación de riqueza; su interés consiste en extraerla de los conductos comerciales cuyo principio motor - sin menospreciar la base agrícola del crecimiento- se ubica en el seno del sistema urbano. Esta fórmula endoparasitaria -en tanto que actúa dentro del propio feudalismo- convive durante el siglo XIII con las formas clásicas de explotación feudal del territorio. Su "éxito» - a nivel local, quizá otro de los factores desencadenantes de la crisis- se fundamentaba en su sencillez: el costo económico y la necesidad de apoyos sociales para la creación de un dispositivo de las características señaladas se reducía de forma drástica, mientras que - por contra- los beneficios económicos eran enormes.

\section{LATORRE EN SU MATERIALIDAD}

\section{Del genotipo-torre a los fenotipos-torre}

La torre es un edificio que se define esencialmente por su altura y sólo de forma secundaria por su fortaleza (GARCía GÓMEZ, 2003: 137), Un fragmento de una Real Provisión de Enrique IV nos servirá para ilustrar este extremo: «algunas torres e Casas fuertes e Llanas de la dicha provincia, quando fui a ella, les mandé derribar e allanar por que los dichos males e dapños que de ellas se facian e se cometian cesasen" (BAZÁN, 1998: 28). Observemos cómo el verbo «allanar» está demarcando el nivel a partir del cual se puede hablar de casa fuerte/torre o de casa llana: parece que bastaba eliminar aquella porción excedente en altura para que la torre dejase de ser un objeto peligroso.

Esta observación nos pone ante una evidencia clave en la edificación de una torre: lo importante es alcanzar altura. Un requisito que se podía cumplir de diversas formas, adecuando las necesidades a los recursos disponibles; no era obligado acudir a un material costoso como la piedra, pues bastaba elevar un edificio íntegramente de madera. La abundante masa boscosa, el menor coste de la obtención y tratamiento de la materia prima influyó de forma decisiva para que se diese el fenómeno de la torre construida íntegramente en material lígneo.

En terminología de análisis configuracional podríamos decir que existió un genotipo de fortaleza banderiza - un concepto prototípico de la misma- al tiempo que se constatan múltiples fenotipos —es decir, diferentes formas de materialización física de aquella idea arquetípica- El genotipo-torre, se plasma en dos fenotipos fundamentales: el fenotipo-torre de madera y el fenotipo-torre de piedra (FERNÁNDEZ-GALIANO, 1991: 86-90).

\subsection{La torre según el modo de destruirla}

Un análisis de las Bienandanzas e Fortunas de Lope García de Salazar resulta esclarecedor (MARín SÁNCHEZ, 2005). Fijémonos en los verbos que utiliza este autor para referirse a la destrucción de un baluarte banderizo. Cuatro son los utilizados con más frecuencia: quemar, talar, derribar y - eventualmente- derrocar: de un total de sesenta y cuatro referencias a destrucciones que se documentan entre los Libros XXII y XXV de la citada obra, treinta y siete utilizan la expresión «quemar», cuatro la de «derribar» mientras que se usan las dos conjuntamente en doce ocasiones. Más raramente se habla de «talar», cuatro veces, y de «derrocar», una sola vez.

La quema debió ser la práctica más habitual. Al ser la madera el componente principal de la torre, aquel era un modo sencillo de acabar rápidamente con la mayor parte del edificio. Pero esta táctica no debía ser la óptima, pues —cuando se daban las condiciones necesarias - se prefería la tala, que permitía recuperar el material lígneo para la estructura de otros inmuebles. Señala Enrique IV, ordenando ciertos desmoches; "que las construcciones sean derribadas e allanadas pero no sean quemadas por que los Dueños de ellas se puedan aprovechar de la madera e piedra de ellas para facer casas llanas en otras partes» (BAZÁN, 1998: 29).

Que incendiar fuera el método utilizado con mayor frecuencia, insiste en la idea de que el principal material combustible era la madera y por lo tanto el fundamento constructivo de las fortalezas de que se servía el pariente mayor. Las constantes referencias en la documentación a estas "quemas» y el estudio de las torres que aún hoy se conservan nos demuestra que, a pesar de que el fenotipo conservado en la actualidad es el de la torre de piedra, su diseño tiene más que ver con el material lígneo y los principios de la carpintería de armar que con la cantería. En este sentido podría afirmarse que las torres pétreas son herederas del fenotipo-torre de madera, aunque ambos tipos convivieran hasta el ocaso de los enfrentamientos. 


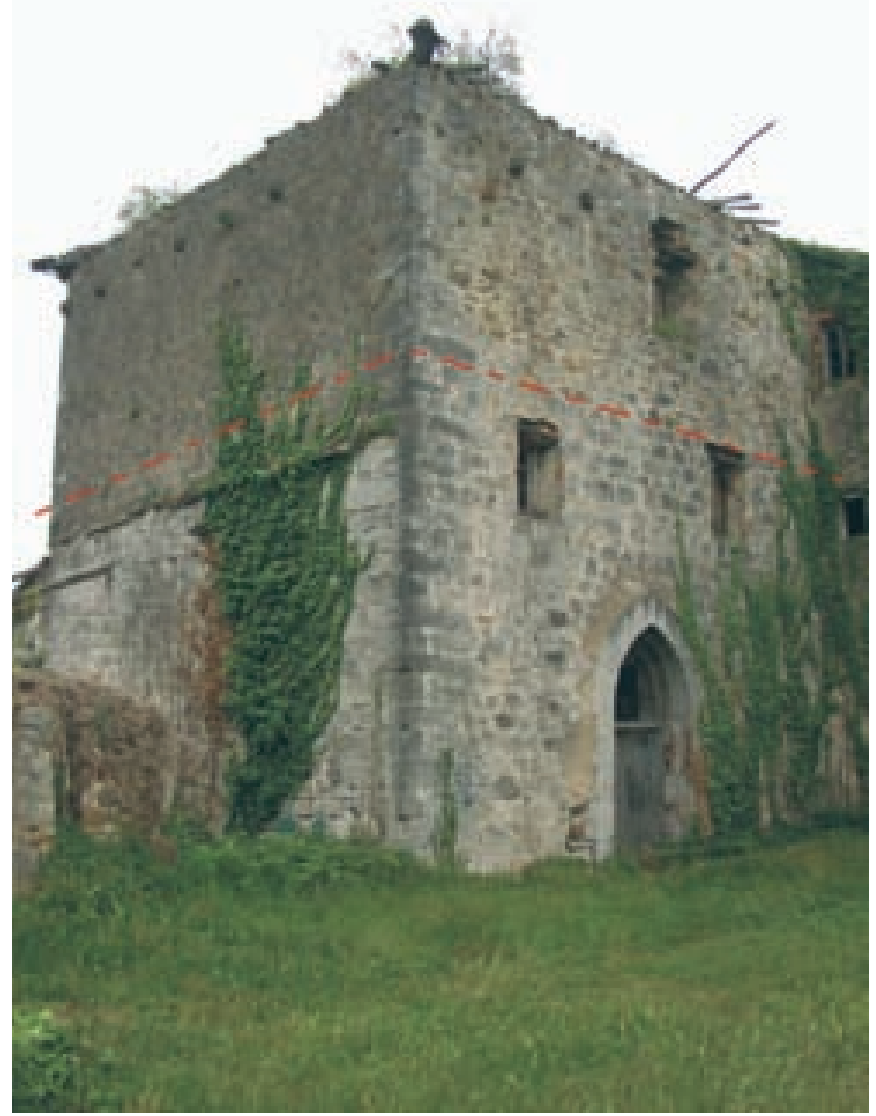

Torre de Madariaga (Busturia, Bizkaia). La línea roja discontinua marca el límite de los dos tipos de fábrica documentados: la parte de abajo corresponde a la fase más antigua del edificio y la superior a una posterior reconstrucción de la torre

El derribo -en una ocasión García de Salazar habla de derrocar-, suponía el desmontaje de la fábrica pétrea de una torre, tarea tremendamente costosa. Según las dimensiones del torreón, y según el reaprovechamiento que se quisiera hacer del material lítico — para transformarlo en cal o para su uso en otro edificio- el esfuerzo necesario para arruinar o desmochar una fortaleza no debía ser mucho menor que el requerido para su construcción.

En nuestros análisis estratigráficos en torres hemos podido documentar dos reconstrucciones, una en la torre de Madariaga (Busturia, Bizkaia) y otra en la de Martiartu (Erandio, Bizkaia). Cada caso presenta sus particularidades, pero ambas nos informan de la gravedad de los actos previos de desmantelamiento (García Gómez, SánChez PinTO, 2003 y 2004). Estratigráficamente, se distinguen en sus fábricas tres fases diferentes: una original —la primera torre que se construye en el emplazamiento-, una segunda de destrucción - que en Madariaga parece guardar las trazas de un verdadero desmoche- y una última de reedificación. En el proceso de reconstrucción existió una dialéctica

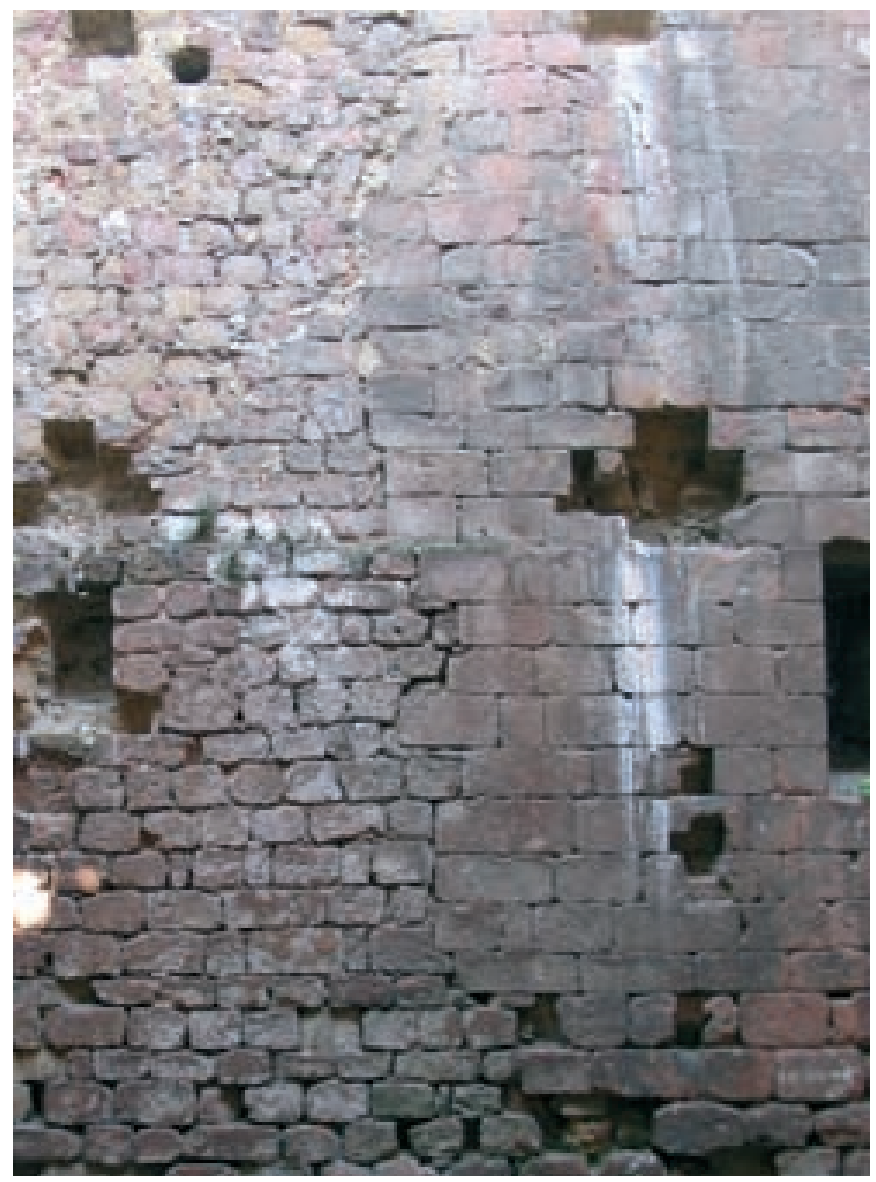

Torre de Martiartu (Erandio, Bizkaia). Claramente discernibles, los distintos tipos de aparejo del interior del edificio: a la izquierda, el perteneciente a la fase más antigua, a la derecha el de la reconstrucción

permanente entre la ruina —es decir los restos de la antigua arquitectura- y el nuevo proyecto constructivo. Las obras de reedificación sólo pretendieron recuperar los valores que se suponían intrínsecos a una torre - altura y fortaleza- pero en esa pretensión se escogieron vías diferentes.

El punto de partida en los dos lugares fueron unas ruinas preexistentes, las cuales contenían aún algunas de las características de la primitiva edificación, a saber, una planta de determinada forma y dimensiones, y unos robustos muros de un grosor concreto. Estas cualidades condicionarían la nueva construcción, pues en rarísimas ocasiones un artífice se planteaba empezar de cero en otro lugar cuando se disponía de un buen trabajo de cantería acumulado con todo el material ya colocado en un punto estratégico del territorio. Las sociedades preindustriales estaban tan naturalmente dotadas para la optimización del esfuerzo humano en función de los medios disponibles que, esa misma cualidad, se convertía a la vez en un factor inercial.

No obstante, las circunstancias en que se produjeron los trabajos no fueron semejantes. Esto se refleja perfecta- 
Cuadro 2

El análisis estratigráfico

Tratar de justificar la necesidad del análisis estratigráfico en arquitectura frente a otras aproximaciones en las que han sido predominantes criterios como el estilo, pudiera parecer un intento más de ahondar en la herida de las confrontaciones disciplinares. No es ésta, sin embargo, nuestra intención.

La arquitectura tiene materialidad, ocupa un espacio y, normalmente, perdura en el tiempo. $Y$ esto que parece una obviedad, tiene su importancia a la hora de investigar en su historia sea desde la perspectiva que fuere, porque la materia y el tiempoespacio entretejen complejas relaciones renovadas permanentemente y que escapan al reduccionismo de las categorías formales.

Cierta materia ocupa determinado espacio en tal o cual transcurso del tiempo, en un proceso que con probabilidad se repite sobre el mismo espacio en tiempos distintos. El resultado no es sino una memoria petrificada de manera muy compleja. Para descubrir cómo esa materialidad se articula de forma ordenada en el tiempo debemos atender a su disposición en el espacio y, especialmente, a su relación contextual con otros materiales depositados en tiempos distintos. Y es aquí donde apreciamos la enorme distancia que separa a las poten- cialidades del análisis estratigráfico sobre otras aproximaciones formales al uso.

Decir, por ejemplo, que las torres bajomedievales poseen tipología diversa y que pueden dividirse en "torres exentas», «torres-fortaleza» y "torres con palacio» no es sino describir la imagen final que de ellas ha llegado hasta nosotros. Una imagen que refleja un tiempo (el nuestro) y que, sin embargo, puede estar ocultando una realidad que vivió tiempos muy distintos: ya nadie discute que un torre con palacio pudo haber sido antes una torre fortaleza y, antes aún, una torre exenta.

¿Cómo podemos superar este viejo problema? Pues desacralizando el objeto, el monumento-fetiche, que no existe en sí mismo como un estilo congelado en el tiempo, sino como la materialización de una memoria histórica fragmentada que necesita previamente ser biográficamente restaurada. Y restaurar significa devolver a los objetos su significado, el valor semántico que tuvieron en el pasado y ello sólo puede conseguirse contextualizándolos estratigráficamente, «porque — como se dice certeramente desde la psiquiatría - un recuerdo no se ofrece como un dato aislado, sino como componente de una

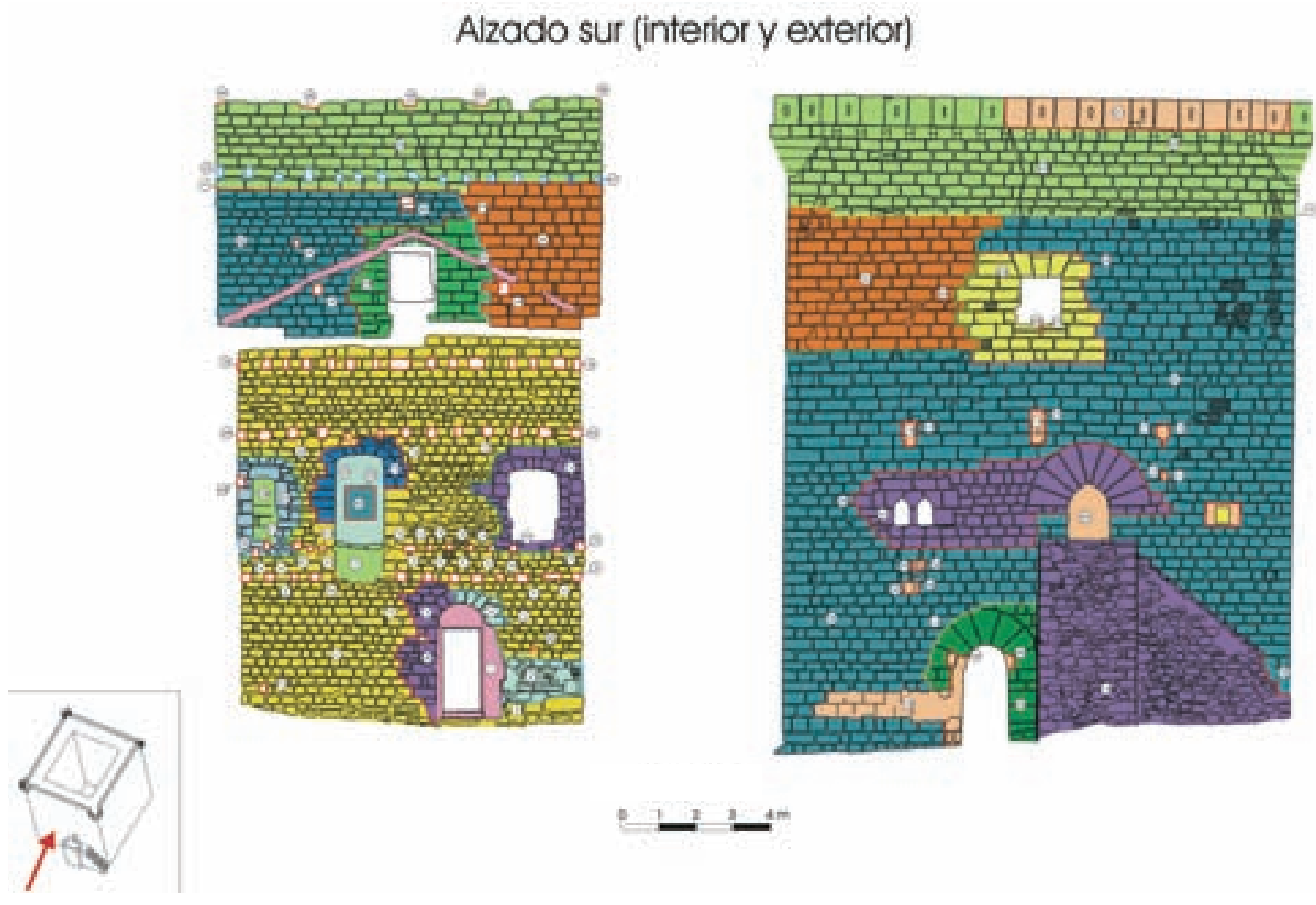

Detalle de la estratigrafía de la Torre de Martiartu (Erandio, Bizkaia). Hasta el momento, para el estudio de las torres, se había considerado el edificio como un todo monolítico, ignorando la complejidad estratigráfica que encierra cada ejemplar 
estructura contextual» ${ }^{1}$, quedando como un estrato. El estudio de la mente, por lo tanto, de nuestra memoria, no puede ser sino estratigráfico. Y otro tanto ocurre con el conocimiento y conservación de nuestro patrimonio arquitectónico.

Y aquí es donde entra en acción el análisis arqueológico. No es casual que los pensadores contemporáneos más relevantes hayan recurrido al concepto de "arqueología» para ejemplificar la naturaleza y alcance de algunas de sus propuestas. Se ha dicho, en este sentido, que M. Foucault, por ejemplo, sin duda uno de los filósofos contemporáneos más importantes, fue «un arqueólogo (es decir) alguien que escrutaba, que leía...

1 Castilla del Pino, C. (1995), «La Memoria y la Piedra», en A. González, C. Castilla del Pino, A. Fernández, Patrimoni: Memoria o malson?, Memoria 1990.1992, Diputació de Barcelona, pp. 9ss. bajo el suelo aparentemente liso y sin texturas de nuestra lógica», tratando de descubrir las "profundas estructuras» del conocimiento.

La disciplina arqueológica trabaja, básicamente, sobre testimonios materiales, sobre retazos de memoria conservados por su propia durabilidad. Estos fragmentos de pasado, aunque aparentemente arrojados al caos de la descomposición, ocupan un espacio que en su articulación ha apresado - materializándolo- el transcurso del tiempo. Es decir, el devenir, el transcurso del tiempo queda como mágicamente apresado en los restos materiales fosilizados. Y esos restos, esos retazos de memoria, únicamente pueden ser reordenados diacrónicamente mediante el análisis de sus relaciones de anteroposterioridad. No a través de analogismos formales (como se ha pretendido reiteradamente), sino a través del análisis estratigráfico. mente en las diferencias perceptibles entre el aparejo de los muros antiguos —en los dos torreones era sillarejo-y los que se emplearon con posterioridad. En el caso de Martiartu las obras introdujeron considerables mejoras en el edificio, mientras que la calidad en Madariaga disminuyó. Allí, el grosor de los muros aumentó, pasando del metro a los 2 metros, y se empleó un aparejo de sillería muy bien labrada y costosa, aunque del mismo tipo de piedra arenisca que en la fábrica antigua. Aquí, un austero aparejo de mampostería caliza con una mínima utilización de la sillería para el reforzamiento necesario de los esquinales. En definitiva, la desigualdad del esfuerzo humano, material y de tiempo empleado en el tajo, quedó impresa en la estratificación, siendo síntoma de los diferentes contextos en que se desarrollaron los trabajos.

Lope García de Salazar utiliza también diferentes sustantivos para referirse al edificio fortificado que va a ser destruido; el mayoritario es el de «casa» — en 35 ocasiones-, en 5 más se cita "casa fuerte», otro tanto se habla de "palacio" y también en 5 ocasiones se emplea específicamente «torre». Pues bien, según las referencias analizadas, cualquiera de esos tipos era susceptible de someterse a alguno de los tres tratamientos - quema, talado o derribo-, salvo cuando se habla de una torre. En este último caso no se da tal variabilidad, ya que la solución destructiva consiste casi siempre en el binomio quema y derribo; sólo en una oportunidad se indica el derribo.

No debe extrañarnos que el cronista prestara una atención especial a estos pormenores; estas destrucciones debían ser algo tan natural y consubstancial al enfrentamiento banderizo que García de Salazar no podía sino registrarlas en sus detalles, de forma prácticamente inconsciente. Lo dicho nos sugiere que, a ojos de éste, la torre se distinguía del resto por sus muros perimetrales de piedra, a pesar de que el cadalso y la estructura interior fueran de madera. Casas, casas-fuertes y palacios debían caracterizarse también por su aspecto fortificado, aunque la gran diferencia entre ellos radicaría en el empleo mayoritario de la madera.

\subsection{La torre según el modo de construirla}

La documentación y los cronistas, salvo casos excepcionales - como veremos para la torre de Berna-, se preocupan bastante poco por la descripción o tratamiento de los aspectos constructivos de la torre, por lo que en la mayor parte de las ocasiones se hace necesario recurrir a análisis cuantitativos como el realizado más arriba. Al contrario, el estudio arqueológico de la estratificación de estos edificios, está aportando un importante volumen de datos que nos aproximan a su realidad material (DOMÍNGUEZ, SÁNCHEZ ZUFIAURRE, 2001).

En las excavaciones que hemos llevado a cabo en el interior de varios de estos inmuebles — concretamente en los casos de las torres de Murga (Álava), Martiartu y Madariaga (Bizkaia) - se ha podido comprobar cómo las fábricas se asientan directamente sobre la roca, sin mediar elaborados de cimentación. Esto nos indica que uno de los factores que más debía pesar en la elección del emplazamiento —además de las consideraciones geoestratégicasera el de la propia solidez del terreno donde se proyectaba la construcción: una mayor cota de afloración del sustrato rocoso era una garantía de solidez y permitía además economizar en el trabajo de excavación. El planteamiento de una buena cimentación era un problema nada sencillo, no tanto por su ejecución, sino porque requería de cálculo, y de unos conocimientos poseídos sólo por los artífices especializados. 
Otro factor a tener en cuenta, debió ser la distancia con respecto a la cantera donde se obtendría el material pétreo. El coste del acarreo podía encarecer desproporcionadamente cualquier empresa arquitectónica, hasta el punto de hacerla impracticable. Por ello, en todos los casos estudiados se observa cómo la litología de la fábrica de la torre, denota siempre un origen local. En otras palabras, se trabajaba con lo que estaba a mano ${ }^{6}$.

Comparado con la erección de un castillo en altura, la elevación de una casa-fuerte requería un menor esfuerzo constructivo. No obstante, en términos relativos, la reunión de una cuadrilla de albañiles - a los que había que mantener- y la consecución de un cierto volumen de materia prima - que tenía que ser trasladada, trabajada, puesta en obra, etc. - no puede considerarse una tarea sencilla. Emprender una empresa de estas características exigía el acceso a una serie de recursos y conocimientos que podían exceder las posibilidades de un noble cualquiera.

Para hablar de los costes de una edificación de las características genotípicas de una torre, debemos distinguir en primer lugar los dos posibles fenotipos, pues no es lo mismo una construcción realizada íntegramente en madera que otra donde se emplee la piedra. El costo del material lígneo sería mucho menor que el de la piedra, ya no tanto por el mayor valor intrínseco de aquél, o por su mayor o menor abundancia, sino por el moderado coste que suponía su transporte y su elaboración.

A pesar del importante salto cualitativo que suponía la edificación en piedra, hay que insistir en la idea de que la obra de carpintería interior era la que determinaba la dimensión y la forma de la torre. En los edificios que hemos estudiado - particularmente en el caso de la torre de Martiartu- nos fue posible constatar cómo el módulo de la planta de la casa-fuerte dependía normalmente de la longitud que podían alcanzar las vigas maestras - la cual obedecía a su vez a la largura máxima aprovechable de un tronco de haya o roble-, condicionando así el resto de proporciones del edificio. Los recientes inmuebles estudiados nos han permitido confirmar que el lado corto en los torreones de planta rectangular y el lado único en los cuadrangulares, oscilan alrededor de los $11 \mathrm{~m}$ de desarrollo, siempre según el grosor de los muros en cada caso (GARCíA GÓMEZ, 2003: 134).

\footnotetext{
${ }^{6}$ Conocemos, por el trabajo de otros investigadores, que existen algunas excepciones en las que se constata la utilización de material pétreo procedente de canteras distantes del emplazamiento de la torre en construcción. No obstante, todos los edificios que hemos podido estudiar directamente responden al esquema esbozado, por lo que creemos que no es temerario extrapolar este dato a la mayoría de ellos.
}

Vamos a fijarnos ahora en un proceso de construcción sobre el cual la documentación aporta interesantes datos cuantitativos que nos pueden ayudar para hacernos una idea de la envergadura de una torre; hablamos de un edificio en piedra, la torre de Berna (BAZÁn, 1998: 23-50).

Parece ser que la citada torre, situada junto al curso del Ibaizabal y regentada por el linaje de los Berna, era motivo de constante desasosiego para los vecinos de $\mathrm{Ta}$ bira de Durango, que en 1442 decidieron y ejecutaron su "toma e quema e derrocamiento». Décadas después, en 1463 , sin contar con la pertinente licencia real, el pariente mayor comienza la reconstrucción de aquella, precipitando el inicio de un pleito en instancias judiciales por parte de los durangueses. Éstos en sus deposiciones señalaron, por un lado, que la torre llevaba en construcción unos cinco o seis meses, y que hasta ese momento habían conseguido elevarse dos plantas. Indicaban también que en los trabajos estaban participando unos cuarenta hombres y que a Fernando de Berna le habían concedido $10.000 \mathrm{mrs}$ para la obra.

Resulta ilustrativo, para comprender la importancia de la red parentelar y entender su fortaleza, observar cómo a pesar de la insolvencia del señor de la torre, éste podía obtener recursos de familias aliadas. En este caso, hombres y dinero eran proporcionados por Juan Alonso de Múxica, oñacino como los Berna, interesado también en el sostenimiento de una torre afín, pues ésta se encontraba en un punto estratégico.

La citada fortificación ha llegado a nuestros días convertida en un sencillo caserío, pero en su fábrica se pueden registrar aún algunos rasgos característicos del antepasado. En esencia, se trata de una fábrica de sillarejo con esquinales del mismo tipo, aunque algo mejor trabajados. Admitiendo que, en los cinco o seis meses indicados, los trabajos no hubieran sufrido alguna interrupción, y contando con un número constante de unos cuarenta hombres, alcanzar tan sólo dos plantas nos da idea de la ardua tarea que suponía una empresa de estas características. A las dificultades de reunir a una cuadrilla con algún especialista se unía el problema del abastecimiento de alimento y materia prima, en un entorno poco propicio por la animadversión de los convecinos. La ayuda del bando se hacía también imprescindible, documentándose en esta ocasión cómo los mulateros de Fernando de Berna traían el trigo desde Aramayona.

Una vez se apoyaba la base de la estructura sobre la roca natural del terreno, se comenzaba la erección del edificio. Las labores de carpintería avanzaban a la par que las de cantería, piso a piso, forjado tras forjado. Estos constituían a la vez parte del andamiaje de la obra, el mismo fin con 


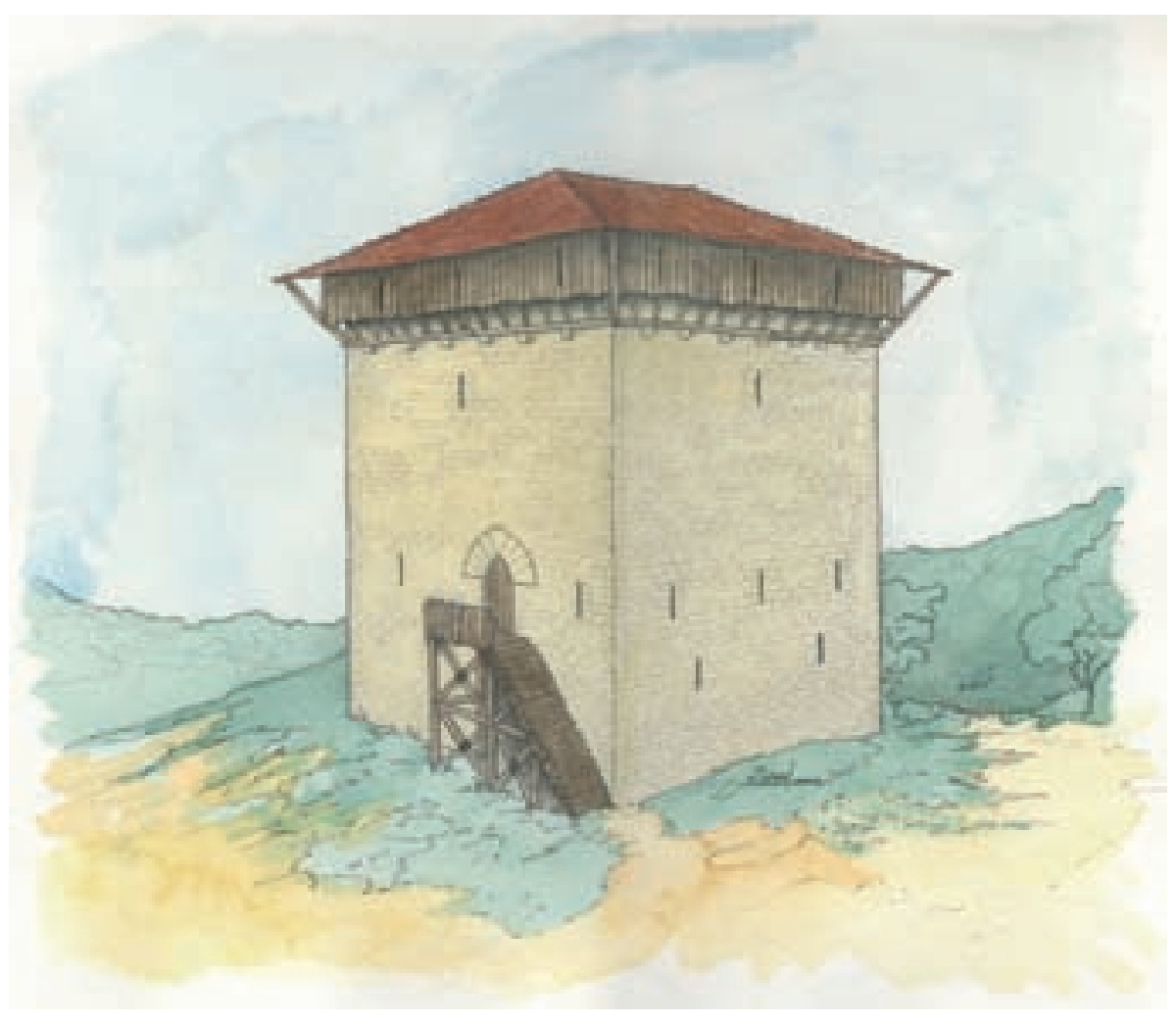

que debieron utilizarse, al exterior, las hileras de ménsulas que aún hoy se pueden observar en muchas torres, aunque su destino último sería el de sostener ciertas estructuras en madera anejas al edificio principal.

Los muros perimetrales habitualmente eran de mampostería, en muchos casos también se utilizaba el sillarejo, y sólo en ocasiones puntuales se utilizaba la sillería. Los vanos y los esquinales en la mayor parte de las torres eran los elementos que recibían un tratamiento más cuidado, normalmente, con recercos de sillería; es en estos lugares donde con mayor facilidad percibimos la mano del artesano especializado en el trabajo de cantería. Pensando en la torre de Berna, y en la cuadrilla de cuarenta trabajadores, debemos formular la hipótesis de unos pocos especialistas en carpintería y en el trabajo de la piedra, mientras que el grueso del equipo estaría formado por trabajadores poco o nada especializados encargados de labores mecánicas sencillas.

Coronando el conjunto se construía el cadalso. Se trataba de una estructura de madera que, aferrada al armazón interno del edificio, excedía perimetralmente los muros en piedra para conformar sobre ella un voladizo, apeándose al exterior sobre una serie de ménsulas o mechinales que solían rodear por lo alto la fábrica. Algunos autores entienden que estas apoyaturas - único testimonio visible que ha llegado a nuestros días de aquellas obras en madera- no tu- vieron por qué funcionar como sostén de ningún ingenio defensivo como el cadalso, siendo sencillamente puntales para la cubierta. No obstante - sin acudir a la cuantiosa documentación iconográfica existente al respecto-, sencillamente, no parece lógico pensar que, en la concepción de la torre, se descuidase un aspecto capital en la práctica de la guerra medieval como era la protección de los pies de una fortificación, ya que éste era uno de sus puntos más sensibles y vulnerables?

Es más, el cadalso situado en altura era el elemento que dotaba de significado militar a la torre - convirtiéndolo en un instrumento operativo-, tal y como nos demuestra el interés que tenía su eliminación como alternativa a la destrucción total del edificio. Hasta en seis ocasiones Lope García de Salazar se refiere específicamente a la quema de cadalsos: "e quemó los cadahalsos de Çugasti e de Leçama e IV casas fuera de la villa e quemó los cadalsos de Fuica e de Juan de Velendis e de Menaca e de Goiría e el cadalso e palaçios de Sant Martín de Arteaga e quemó e derribó la torre e palaçios de Olariaga».

Finalmente, sobre el cadalso se colocaba la cubierta, que debemos suponer con un tejado a cuatro aguas, pues —aunque más costosa - era la forma más adecuada para

\footnotetext{
$7 \mathrm{Al}$ respecto, ver cuadro n. ${ }^{\circ} 3$.
} 


\section{Cuadro 3}

Sobre los atributos de la torre: el cadalso y los desmoches

En el caso de la torre, nos encontramos efectivamente ante un edificio que sirve como residencia señorial, pero que funciona por encima de todo como una fortaleza con fines militares. La torre no era el único refugio donde podía vivir el señor, aunque sí el único que le permitía defenderse en los momentos de peligro, y sin duda, era el instrumento más eficaz para conseguir el control del territorio y de las rutas de intercambio. Por supuesto, para su cometido debía estar adecuadamente dotada - no tiene sentido atribuir una funcionalidad a un edificio cuando materialmente no cuenta con las características necesarias para cumplirla- y por ello, del mismo modo que sin rueda de moler no hay molino o sin horno no hay ferrería, creemos que sin cadalso no hay torre.

Más allá de los arquitectos, los historiadores del arte o los arqueólogos ¿quién mejor que un molinero para explicar cómo es un molino? ¿quién mejor que un clérigo para mostrarnos cuan íntimamente van unidas la liturgia y la forma de un templo? Y entonces, ¿por qué no acudir a los especialistas en las llamadas artes militares para analizar las torres? No podemos tomar sólo en consideración los principios básicos de la tradición constructiva y prescindir del conocimiento de las técnicas de fortificación medievales y de la poliorcética.

En las torres que estudiamos arqueológicamente, la necesidad de comprender la estratificación y los procesos que la habían generado, nos exigió ir más allá de la descripción formal de las partes del edificio; había que conocer la justificación funcional de cada uno de sus elementos, pues sólo así podíamos lograr un discurso razonado de la evolución constructiva del inmueble. En unas ocasiones las justificaciones deducidas fueron de tipo constructivo o estructural, en otras de tipo práctico —en relación con los usos domésticos del inmueble-, algunas fueron las de tipo estético u ornamental, pero también muchas de las respuestas las encontramos en la observación de los principios de la poliorcética medieval.

Hasta que las armas de fuego no evolucionan lo suficiente como para conducir a un replanteamiento de las técnicas de asedio y defensa de las fortalezas, la guerra medieval fue sobre todo una cuestión de altura. La gran ventaja para los defensores de torres y castillos no radicaba tanto en el grosor de los muros (no había casi peligro, después de todo las técnicas de artillería y zapa eran muy rudimentarias) sino en la altura que alcanzasen aquellos. Estar situado a una mayor altura dificultaba la accesibilidad al enemigo y sus proyectiles, pero sobre todo, permitía que los dardos de las ballestas y las flechas de los arcos defensores tuviesen el máximo radio de alcance posible. Mantener la amenaza a distancia era clave, de ahí que — siempre que fuera posible construirlos — se producía la acumulación de anillos amurallados en torno a la fortaleza principal.

No obstante, no siempre era posible mantener esa distancia de seguridad, y muchas veces el atacante se podía colocar a los pies de los muros, desde donde actuaba con total impunidad contra la fábrica del edificio. La vulnerabilidad de esta parte de una torre era un aspecto crítico de su protección, por lo que desde el siglo XIII (SAILHAN, 1991: 149), como contramedida, se generalizó el uso de unas estructuras de madera que sobresalían en lo alto sobre el desplome de los muros. Éstos entramados se conocieron con el nombre de cadalsos (hourds en francés o brattices en inglés), los cuales permitían flanquear de

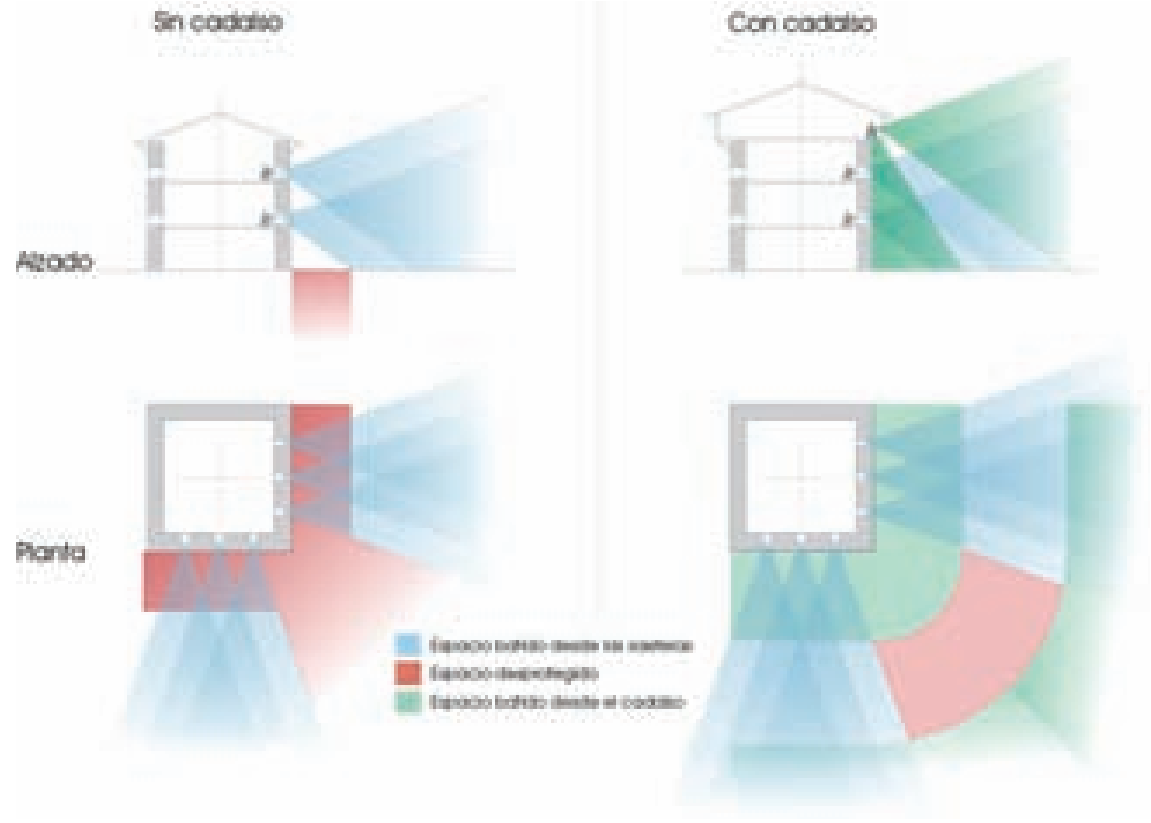

Poliorcética. Comparación de la vulnerabilidad de la torre sin cadalso - que deja los pies de la fortaleza desprotegidos- frente a la torre con cadalso - que además de permitir un mayor control a distancia, evita el ángulo ciego en la base del edificio- 


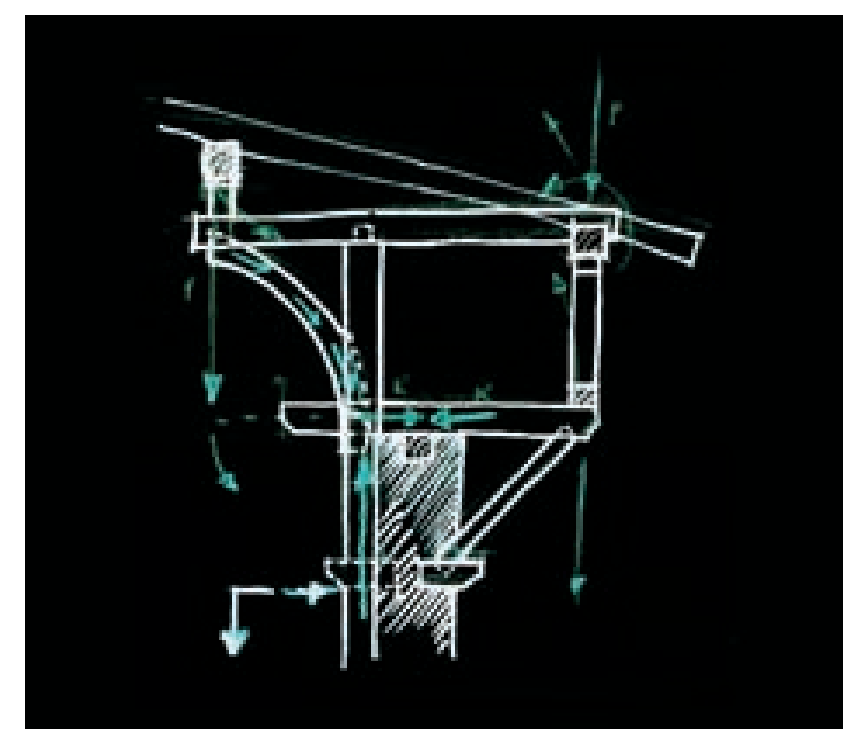

Sección de la torre, a la altura del cadalso, donde se muestra el modo en que - con el empleo de las técnicas de la carpintería de armar del momentose pudo configurar el entramado de dicha estructura para sostenerla sobre una única hilada de ménsulas (Croquis: Ander de la Fuente)

forma efectiva la falda del edificio. Si bien no han llegado a nuestros días restos de estos dispositivos, en alguno de los casos más espectaculares, como el de la Torre de Orgaz en Fontetxa, la de los Ayala en Quejana o la de los Varona en Villanañe — todas ellas en Álava- se conserva la evolución en piedra de aquellos, los matacanes.

Sin cadalso la efectividad funcional de la torre como instrumento bélico es nula. Por numerosas que fueran las saeteras que se contasen en su fábrica, al estar situadas en el mismo plano de los muros y no poder por tanto flanquearlo, el papel de éstas sólo podía ser complementario (SAILHAN, 1991: 78-81). Además, su configuración material —al menos en las torres estudiadas - nos indica que la mayor parte de ellas son en realidad simples vanos de luz.

En nuestra opinión, aunque desde el punto de vista de la tradición arquitectónica vasca no parezca impropio proponer que las ménsulas o mechinales que algunos ejemplares conservan en lo alto de su cuerpo sirvieran únicamente para sostener el alero de una cubierta (CEMBELLín, 2004: 212-213), desde la perspectiva poliorcética, supone despojar a la torre de aquello que la convierte, precisamente, en torre, el único elemento construido que lo habilitaba para poder ofrecer una resistencia activa. Desde el punto de vista constructivo bastaba con una hilada de ménsulas o mechinales para sostener el cadalso, con tal de que la estructura formase un solo cuerpo junto con el resto del entramado interior de madera.

Aunque actualmente no se conservan ejemplos en torres, sabemos que la carpintería de armar de la época disponía de soluciones técnicas muy desarrolladas —no olvidemos que los primeros ejemplares se construyeron completamente en madera-. Puede que se realizase un diseño conjunto cadalso-cubierta, buscando la adecuada distribución de los esfuerzos generados por toda la estructura sobre un sistema interior de pies derechos y corvas, el cual absorbería las cargas que, de otro modo, habrían afectado a la integridad de los muros de piedra. Creemos que es precisamente esta indisoluble relación entre la idea torre y la idea de cadalso - tanto desde la perspectiva poliorcética como desde la construida-, lo que hizo que en la documentación escrita, en muchas ocasiones, se empleara la palabra cadalso para referirse a la torre en toda su globalidad.

El edificio es un instrumento. La torre imponía su dominio por medio de la altura y, sobre todo, gracias a ese cadalso que situado en el remate superior la convertía en una mortífera máquina de guerra. Eliminar esas dos cualidades era casi tanto como destruirla. En nuestra opinión la razón de que Enrique IV en sus mandados hable de "derribar e allanan ciertas torres (CEMBELLÍN, 2004: 151-153) responde a un deseo de distinguir dos posibles puniciones: por un lado el derribo total del edificio — que suponía no sólo la eliminación de sus elementos fuertes sino también la destrucción de la residencia de su dueño - y por otro el desmoche — vale decir, la eliminación del cadalso y una parte importante de la altura de las fábricas para convertir la torre en una casa llana, un recinto aún habitable-.

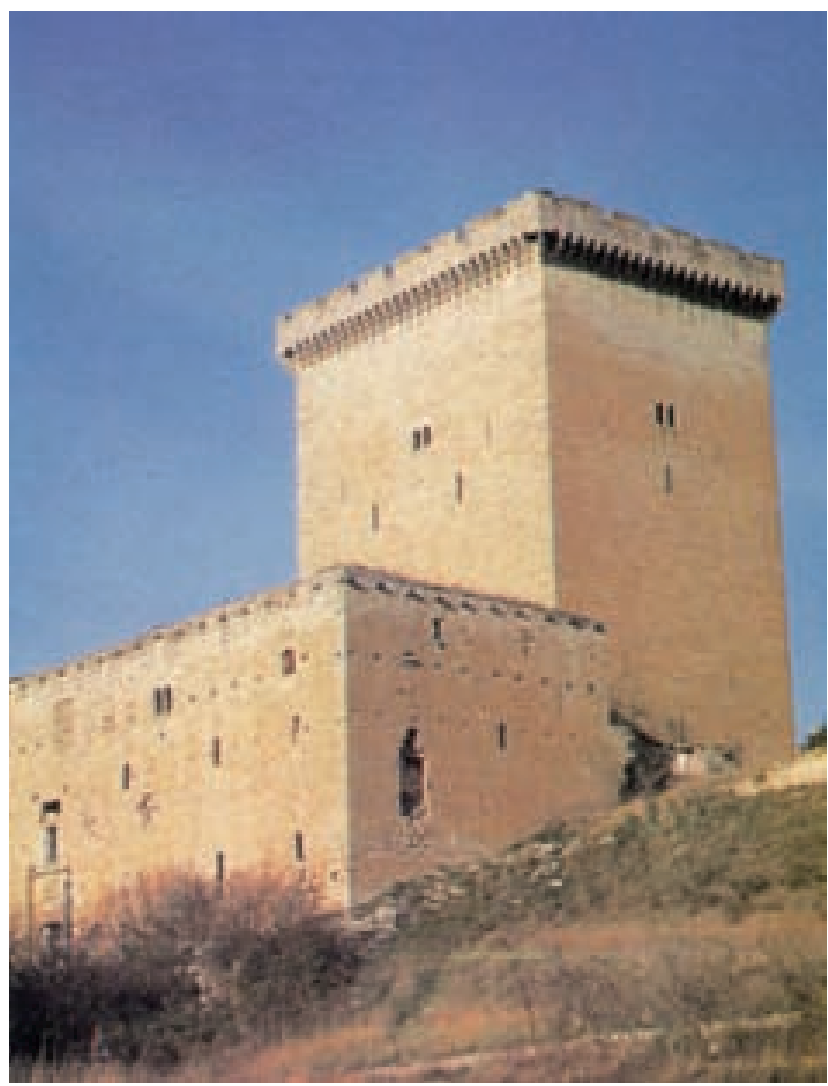

Torre de Orgaz (Fontetxa, Álava). Durante la lectura estratigráfica de alzados se comprobó que el matacán que presenta en la zona superior es original del edificio (Foto: J.L. Barroso) 
proteger de las filtraciones a un edificio de estas características. No contamos con datos precisos de época que nos informen de las características de ésta última, pero basándonos en la observación de estructuras más tardías - como por ejemplo en ocasión de nuestro estudio en la torre de Murga- está claro que éste debía ser uno de los puntos donde el maestro carpintero tenía que demostrar su saber hacer. De su eficiencia dependía directamente la integridad del inmueble, puesto que las filtraciones de agua minaban a medio plazo la fortaleza de toda la estructura interior, amén de convertir el interior del edificio en un lugar más inhóspito de lo que de por sí ya era.

\subsection{Análisis configuracional de la torre: la domesticidad sometida a lo militar}

La configuración espacial de la torre encierra, como resulta evidente, una serie de particularidades que están directamente relacionadas con las necesidades militares que provocan su diseño genotípico. En la torre de Murga (GARCíA GÓMEZ, 2003: 131-138) tuvimos la oportunidad de acercarnos a esta interesante cuestión, por lo que aquí no pasaremos de citar sumariamente algunos aspectos en cuanto a su distribución espacial típica.

Un aspecto a tener en cuenta es el de la predominancia de la circulación vertical. Del mismo modo que la clave configuracional en los inmuebles con una preponderancia del espacio extendido en horizontal se reparte entre los pasillos y accesos que comunican las estancias situadas a una misma cota, en el caso de las torres el estudio de las comunicaciones en vertical - las escaleras sobre todo- adquiere una gran relevancia.

La atalaya —el cadalso situado en lo más alto- es el corazón funcional de la fortificación, pues sólo desde allí se puede ejercer una defensa activa. Por ello —al tiempo que punto neurálgico ansiado por los atacantes-, éste será el último lugar donde se recogerán los encargados de la protección de la torre. Para dificultar el acceso a la atalaya era necesario reducir todos los posibles caminos a uno sólo; de modo que las fuerzas resistentes pudieran concentrarse en puntos concretos del recorrido. Ese itinerario forzoso comprendía, primero, la entrada de la torre —obstaculizada por un patín defensivo y una escalera desmontable - y segundo, los tramos de una misma escalera de ida y vuelta, que piso por piso conducían al cadalso superior.

Sólo remarcaremos otro detalle al respecto. En las torres que hemos podido estudiar estratigráficamente, hemos observado cómo los accesos que presentan las fábricas a ras de suelo son siempre posteriores a la construcción original del edificio - Martiartu y Murga, por ejemplo- salvo cuando la presencia de un patín en piedra garantizaba la inaccesibilidad del mismo -Madariaga o la torre de la Casa del Cordón en Vitoria ${ }^{8}$ -

Lope García de Salazar en varios de sus episodios, nos da una idea relativa de cómo se configuraba defensivamente la torre. En el caso que vamos a citar, el baluarte hostigado parece encontrarse rodeado además por una empalizada de madera: "e entrándoles las varreras, mataron alli, al pie de la torre dentro de las varreras, a Sancho Marroquin de Miono e a Diego Varral de Miono, su primo, e otros dos o tres. E suviendo por las escaleras del antepecho, fueron a Sancho por el través e a Pero López de la Sierra e a Pero López de Garaiçal e a otros. E al recogerse de la casa, tiraron una lança d'ençima de la torre e, fuendo saltando de quima en quima, diole a Juan de Salazar de los Canpos por los nucres, cavo la rodilla, cortándole; d'ello morió luego del floxo de la sangre».

Nótese que todo lo que era ventaja para la defensa se convertía en inconveniente para la habitabilidad del recinto - un problema que se añadía al de la humedad, la escasez de luz y la pobre ventilación-. No cabe duda de que los señores tuvieron la torre como su residencia por antonomasia. No obstante, la prolija presencia en la documentación de menciones a otro tipo de viviendas — casas, palacios, etc.-, nos plantea la cuestión de si habitaban siempre en aquellas, o las utilizaban tan sólo en determinados períodos, quizá de peligro.

La presencia de un único recorrido que atravesaba todas las estancias del edificio hacia la zona de la atalaya - con excepción de la planta baja - parece indicar la inexistencia de espacios privados. En el caso de Murga sin embargo, se documentan dos tramos diferenciados de escalera que comunican un mismo espacio de la segunda planta con el de la atalaya, lo cual podría ser señal de la presencia de un mínimo ámbito reservado — separado mediante tabiquería de madera o verganazo, hoy día desaparecida-, acaso para el señor.

En cualquier caso, esta situación no debe extrañarnos, pues en la Edad Media la casa era un lugar esencialmente público y no privado. Las diferentes funciones domésticas — cocinar, comer, dormir, recibir invitados, etc.- convivían en los mismos ámbitos; bastaba con mover de sitio los escasos muebles según las necesidades. La vivienda del señor debió contar con un gran pulso vital, ocupada por un grupo humano que no se reducía a la de la familia estricta, pues allí también residía el resto de atreguados; amigos, protegidos, sirvientes u otros. «En la Edad

\footnotetext{
${ }^{8}$ La originalidad de los accesos inferiores en unión con la torre es una cuestión que aún se encuentra en debate y los resultados que se alcancen dependerán del sistemático estudio estratigráfico de un mayor número de inmuebles.
} 
Media la gente no vivía tanto en sus casas como acampaba en ellas» (RYBCZYNSKI, 2001: 38).

\section{LA TORRE COMO GESTOR DEL S.A.B}

Como creemos que se deduce de lo hasta ahora dicho, la torre no es sólo un edificio, no sólo la vivienda del pariente mayor, es por encima de todo una función socio-económica y política convertida en estructura física. Es el resultado de la continua interacción de determinados comportamientos sociales, económicos y políticos que acaban dando lugar a la creación del dispositivo. La casa-fuerte es un mecanismo que permite al sistema autorreproducirse y perpetuarse en el territorio, fijarse a él, con lo que se convierte en un factor retardatario, resistente a los cambios de todo tipo. El recuerdo de una casa-fuerte construida en madera es bastante más fácil de eliminar con provocar un incendio, que el de una torre con sus muros de piedra que no puede arder, y que - hasta el desarrollo de una artillería eficazsólo puede ser desmontada con el empleo de un gran esfuerzo económico y humano.

Los criterios del pariente mayor no tendrían el mismo peso sin la existencia de la torre, es más, la evolución constructiva de ésta —el paso por una primera generación de edificios sólo en madera y la posterior aparición de un gran número de ejemplares en piedra- nos está hablando sintomáticamente del lento proceso de emergencia social del banderizo.

Cuanto mejor afianzada sobre el territorio, la torre se convierte en el árbol que ofrece el mejor cobijo. A su sombra, el resto del sistema arquitectónico banderizo se encuentra bien protegido y puede, por tanto, desarrollarse y ofrecer los mejores frutos.

La torre es una garantía de seguridad, pero la clave se encuentra en su papel como gestor de los recursos. Por ello, en la ubicación de las diferentes partes del sistema arquitectónico banderizo el criterio defensivo no es el que prevalece, y sí, el criterio logístico. Un emplazamiento cercano a un punto fuerte del linaje es sólo una ventaja añadida que no tiene ningún valor si previamente no se cumplen los debidos requisitos de accesibilidad a la red de intercambio propia del linaje. Podríamos decir que la condición de dominio implicaba conectividad, lo que podía traducirse tanto en una proximidad con el solar originario, como en una gran distancia mediada incluso por importantes accidentes geográficos.

En fin, la torre es el argumento principal del «más valer» y no sólo por su indiscutible capacidad coercitiva, sino por su profusa y perenne implantación en el espacio. El banderizo se sirve de ella para someter a la parroquia, desde allí administra y gestiona la riqueza proveniente de las imposiciones decimales, también desde allí dirige sus ferrerías, sus molinos, etc. — como venimos diciendo-, por obturación controla los ciclos productivos clave. Por obturación controla también el flujo comercial.

\subsection{Dispositivo de enrutación ${ }^{9}$}

Aunque somos conscientes de que el edificio es un instrumento en manos de una serie de individuos que se sirven de él, y que son en primera instancia los que ejercen el dominio - ellos son quienes pretenden controlar el territorio, el comercio y demás-, optamos por el sujeto-torre, en la medida en que percibimos que sin éste el pariente mayor tendría verdaderas dificultades para mantener su nivel de renta y su peso específico dentro del sistema social bajomedieval. Dicho esto, volvamos sobre la idea de la torre que controla y orienta.

La torre es un dispositivo de enrutación que pone en comunicación una red local —dígase la formada por el S.A.B. - con la red regional, es decir, con el sistema urbano. Creemos que este es un aspecto que no se ha tenido muy en cuenta en el estudio de la configuración de las parcialidades durante la lucha de bandos y que, sin embargo, tuvo que influir de forma decisiva en las estrategias familiares a la hora del establecimiento de alianzas entre las diferentes parentelas, así como en la opción de reforzar unas vías de comunicación frente a otras. Resulta evidente observar que el tráfico comercial y de personas prefiere las rutas estables, exentas en lo posible de bandidaje y con una infraestructura mínima de puntos de recogimiento y abastecimiento. En este sentido, la torre que controlaba un paso o puente podía convertirse en un argumento a favor o en contra que determinaría la elección de uno u otro camino en la planificación del viaje.

Muchos son los casos conocidos al respecto, como el de la torre de Berna (siglo XV), cuya ubicación —al Norte de Durango - pesaba de forma importante a la hora de escoger un camino para llegar a la meta deseada. Parece que los Berna habían extendido el terror entre sus vecinos de la merindad y también entre todos aquellos que debían pasar por el camino real que comunicaba Durango y Bilbao, hasta el punto de que muchos eludían el citado camino dando un gran rodeo: "yvan por otros caminos e senderos e destajos e atajos por el grant miedo que auian de los de la dicha casa» (BAZÁN, 1998: 43).

\footnotetext{
9 En este caso, el neologismo procede del mundo de la informática, donde el estudio, conocimiento y diseño de redes en relación con Internet ha permitido la elaboración de un vocabulario muy preciso a la hora de definir los modos en que se establecen las relaciones entre los puntos nodales de un sistema.
} 


\section{Cuadro 4}

\section{Espacio hodológico y control por obturación}

Disentimos de la idea expresada por González Cembellín en las conclusiones de su trabajo, donde señala que «en contra de una arraigada teoría, la presencia de molinos, ferrerías y templos no parece haber tenido una especial incidencia en la ubicación de las torres». Desde nuestra perspectiva, su afirmación parte de una concepción reduccionista del espacio, entendiéndolo sólo como soporte, lo que conduce a limitar el campo de acción de la torre al terreno inmediato a ella. Creemos necesario reivindicar que el espacio además de soporte, es un medio (SÁNCHEZ, 1991: 8), siendo las vías de comunicación que cubren el territorio la plasmación de una necesidad elemental de movimiento, inherente a toda sociedad humana que depende del constante intercambio de recursos.

En nuestra opinión, si se reconoce que el trazado de los caminos es un "verdadero polo de atracción/estímulo de linajes y, por lo tanto, de torres» (GONZÁleZ CEMBELlín, 2005: 379) no se puede negar, por una mera razón de adyacencia, la presencia de toda relación física directa entre aquellos centros de producción que tenían interés para el señor. «La conjunción física de torres y molinos es inusual, (...) no resulta claro que fuera la presencia de un molino lo que decidiera la ubicación de la torre» (Ibidem, 178). Creemos que la ubicación de molinos, ferrerías, templos y puentes es determinante en la elección del emplazamiento de una torre. Sin embargo, no será el criterio de proximidad el único a tener en cuenta: la clave está en la conectividad, es decir, en las posibilidades que ofrece una ubicación para el control y acceso a una red viaria más o menos extensa.
Hoy día estamos habituados a orientarnos con soltura por medio de planos bidimensionales cada vez más detallados y recurrimos frecuentemente a los mapas temáticos para reforzar la argumentación de nuestros discursos historiográficos, señalando límites fronterizos, enclavando ciudades, campos de batalla, rutas comerciales, torres banderizas, etc. Sin duda, son un instrumento fundamental para aproximarnos a la trama geográfica que subyace en todo fenómeno histórico; ahora bien, deberíamos ser conscientes de que éstos sólo pueden mostrar descriptivamente ciertas particularidades del despliegue territorial de los hechos históricos y, sobre todo, deberíamos tener muy en cuenta que la comprensión de un mapa actual requiere una forma de comprender el espacio muy concreta, precisamente aquella de la sociedad actual. Como se puede comprobar revisando las representaciones cartográficas medievales, los parámetros por los que se regía el diseño de mapas eran completamente distintos de los nuestros y estaban íntimamente relacionados con un modo también distinto de entender el espacio geográfico.

No es difícil delinear sobre un mapa actual el trazado de las rutas comerciales que atravesaban en el siglo XV las tierras vascas, pero ¿qué información nos puede aportar con respecto al método que utilizaba el viajero medieval para llegar a su destino sin perderse? ¿Cómo se orientaban los hombres en el camino? Aparentemente, la respuesta nos la da el puro sentido común, por lo que podríamos esperar que la contestación de un transportista que utilizaba un carro de bueyes, fuera básicamente la misma que podríamos esperar de uno que hoy utilizase un camión. Y sin embargo — probablemente- nos vería-

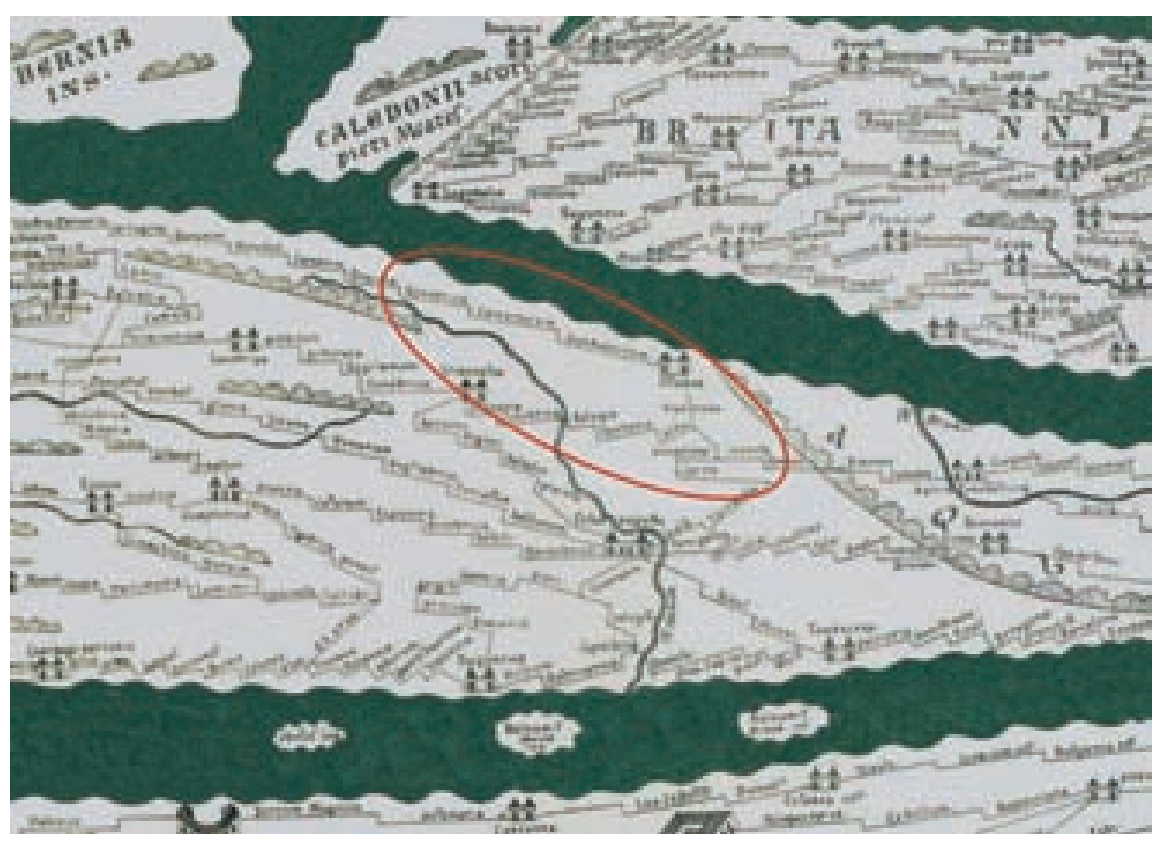

En la «Tabula Peutingeriana», copia medieval de un mapa de carreteras tardorromano, queda perfectamente ejemplificada la forma unidimensional — basada en itinerarios - con que el hombre medieval concebía la geografía. En el círculo rojo, la zona correspondiente espacio vasco 
mos sorprendidos debido a la particular forma de entender el territorio que se da en cada caso. Mientras que en la actualidad concebimos el espacio geográfico en base a parámetros bidimensionales o tridimensionales, aquél arriero medieval lo entendía únicamente como un puñado de recorridos o itinerarios posibles, como líneas que secuencialmente conectan puntos, es decir; de forma unidimensional. Este último modo de pensar el espacio es el que la investigación histórica actual conoce como «spazio odologico» (respetamos aquí el original italiano), término con el cual se pretende diferenciar la mentalidad cartográfica y espacial que ha dado lugar al mapa - propia de nuestro tiempo- de aquella en que el itinerario ocupaba un lugar central. Como nos recuerda P. Janni, «el itinerario y el mapa representan dos etapas en el largo camino del desarrollo de la consciencia, en la evolución de ser que construye en torno a sí la representación del mundo, progresando siempre hacia una mayor objetividad. Quien lista una serie de localidades, en el orden en que aquellas se suceden y con las respectivas distancias, conoce aquello que las cosas son para él, poniéndose a sí mismo como punto de referencia, mientras que quien traza un mapa considera las relaciones objetivas entre las cosas. El itinerario me vale a mí que recorro un cierto camino: las localidades están colocadas en el orden en que yo las encontraré, y las distancias que están medidas a lo largo del recorrido servirán para darme la medida del tiempo y del esfuerzo que tendré que emplear. El mapa representa una red de relaciones espaciales tomadas desde un punto de vista que no tiene una correspondencia directa con mis necesidades inmediatas, ni con mis intereses» (1984: 82)

En una Edad Media de rudimentarios medios de transporte, la unidemensionalidad del espacio era algo más que una categoría mental, era un hecho físico. Aunque los sentidos lo percibían, aquel espacio que no es practicable para los vehículos del momento, no tiene valor como medio de comunicación. Desde esta perspectiva, entendemos que la operatividad logística del S.A.B. no radicaba tanto en la proximidad de los diferentes centros de explotación con respecto al centro de control - que era la torre-, sino en su conectividad, es decir, en la posibilidad efectiva de poder recorrer libremente y sin interrupción un itinerario entre dos puntos, independientemente

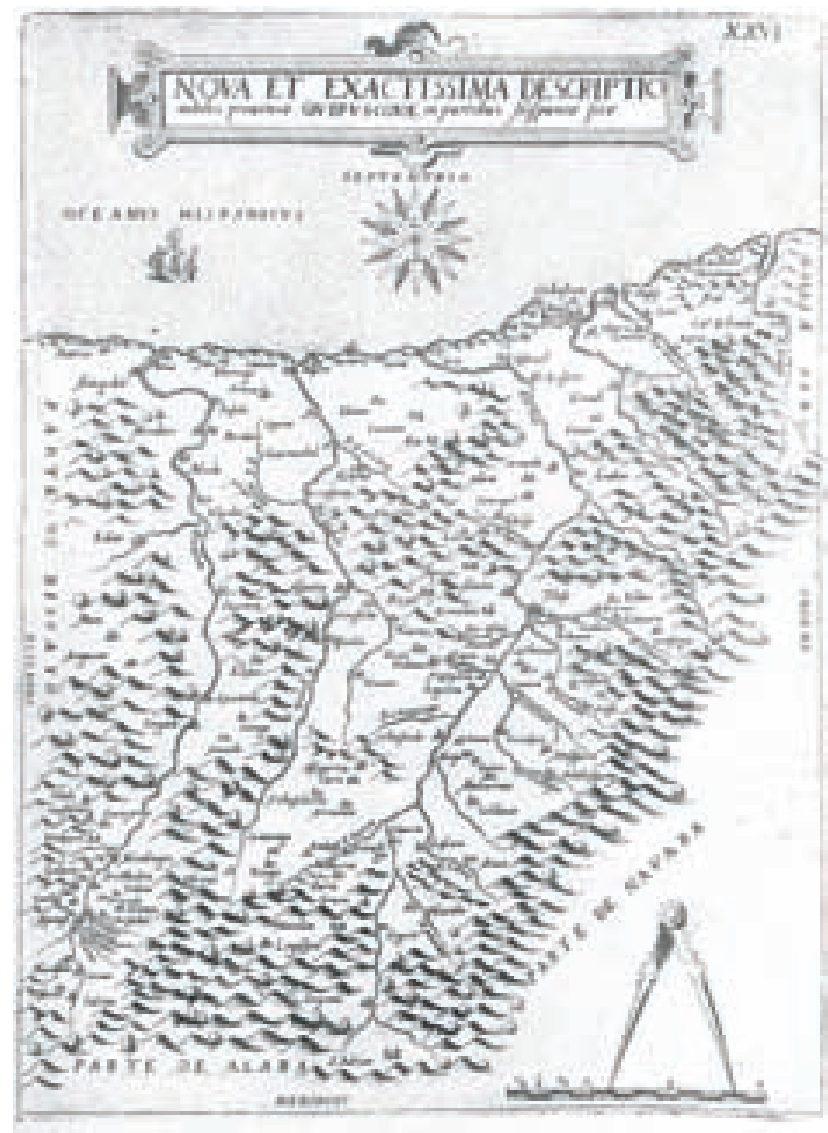

Cornelis de Jode. «Nova et Exactisima Descriptio nobilis provincia Guipuscouae in partibus Hispania sita». Hasta el siglo xvı, no se superó la idea unidimensional del itinerario para la concepción del espacio geográfico; fue entonces cuando apareció el mapa

de la distancia que mediase entre ellos. Está claro que la torre, como elemento de control territorial, no puede ser estudiada al margen de la concepción y la percepción del espacio por parte del hombre medieval.

Conectividad y proximidad son conceptos que no forman parte del vocabulario habitual del historiador, y sin embargo otras ciencias humanas los tienen por elementos capitales a la hora de investigar sobre el modo en que las sociedades utilizan

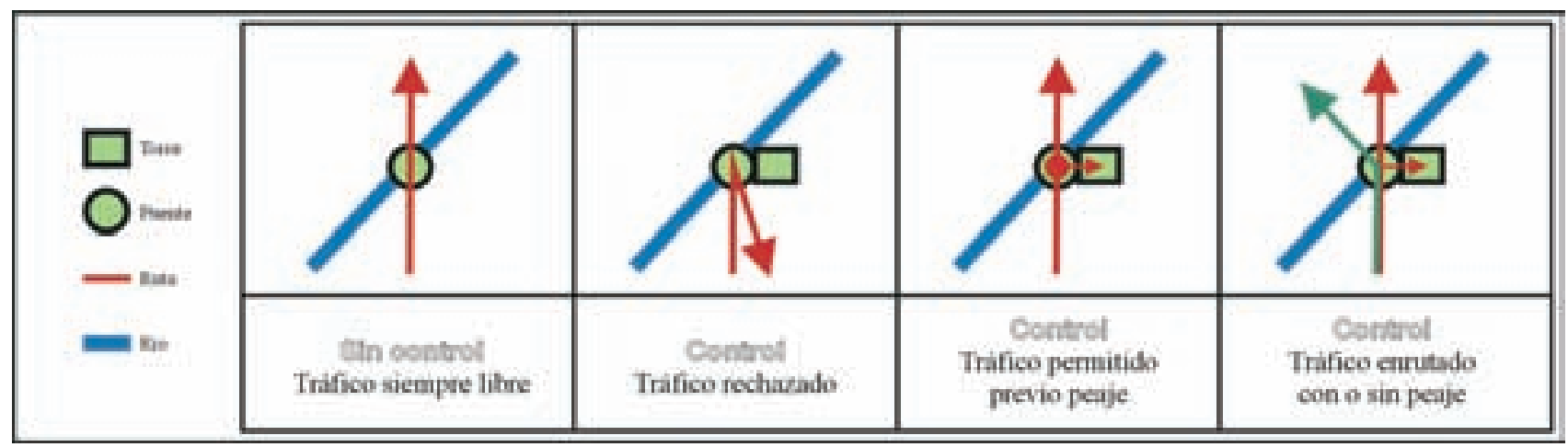

Esquema del modo en que la torre puede alterar el normal flujo comercial en aquellos puntos de las rutas que controla 
el espacio. Numerosos estudios han puesto de manifiesto la existencia de importantes desajustes entre el espacio percibido por el individuo y las dimensiones reales de dicho espacio. El hombre, dependiendo de su bagaje cultural, organiza de distinta manera la información espacial de su entorno, una organización que «determina comportamientos como: quedarse o moverse, dónde ir, qué camino seguir, qué medio de transporte utilizar, etc.» (ZÁrATE, 1991: 182-183).

En fin, la superposición de un conjunto de itinerarios genera en última instancia una red con unos determinados puntos de confluencia. Unos nodos neurálgicos que aparecen allí donde los caminos se entrecruzan, por la obligación de superar algún obstáculo que a veces es un accidente geográfico - como un río o el estrecho tramo de entrada a un valle- y en otras ocasiones tiene un origen artificial —como las murallas de una villa-. Para salvar aquellos había que utilizar el puente o el portal del cinto defensivo. Pues bien, elíjase uno de estos nodos clave de las comunicaciones y edifíquese allí una nueva torre; cuanto mayor sea el número de itinerarios que coincidan en ese lugar mayor será el control ejercido por la nueva construcción.

Torre/puente, torre/portal o torre/paso conformaban así poderosas infraestructuras de control —ya no sólo de los transportes en las grandes rutas - sino también, y sobre todo, del intercambio local. El hierro desde la mina a la ferrería, el grano en su ida para la molienda —o para su depósito en los hórreos del templo local como pago de los diezmos- en fin, la propia movilidad de las personas quedaba sujeta al señor que detentaba la torre. Una forma de dominio del territorio, que nos parece adecuado denominar "control por obturación», en tanto que la torre cumple la función de interruptor: abriendo el paso o cerrándolo, a voluntad.

\subsection{La torre y la estructuración del conflicto banderizo: sistemas bipolares}

Las torres salpicaban por completo todo el espacio geográfico entre villas — poco a poco, incluso el interior de éstascon lo que podemos hacernos idea de la dificultad que implicaba trazar una ruta "segura» para atravesar el territorio. El beneficio que se obtenía del control por obturación de los flujos del intercambio, evolucionó en la intervención y di- seño de los cauces por los que éstos debían discurrir, y esta posibilidad de participar en la configuración de las diversas rutas comerciales acabaría permitiendo al pariente mayor intervenir directa y decisivamente sobre la actividad mercantil.

En el modelado de las citadas rutas sin duda tuvo mucho que ver la pujanza - localmente heterogénea- del propio comercio, pero también debió ser decisiva la inge-

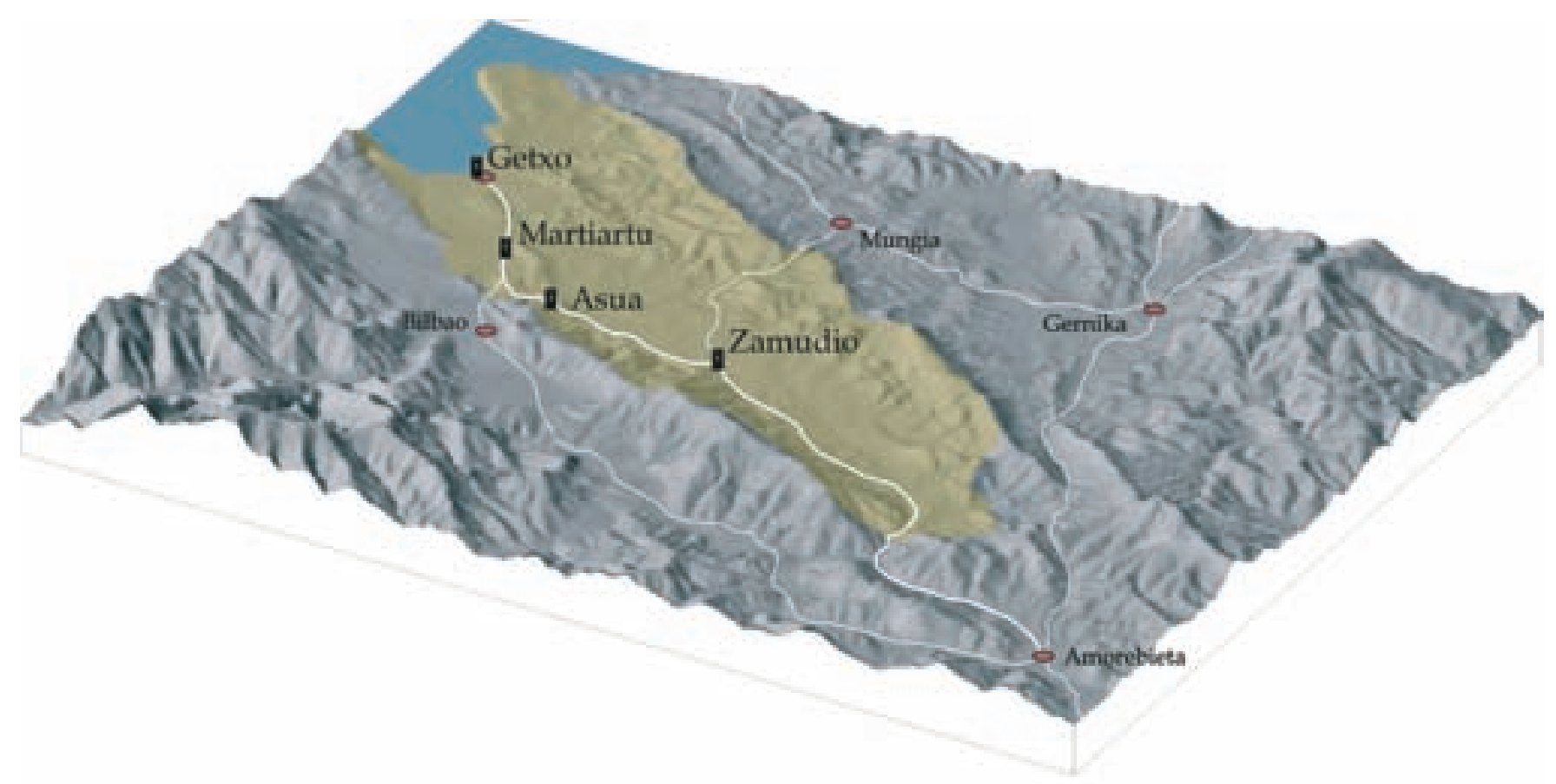

Cuenca fluvial Asua/Gobelas/Udondo, al norte de Bilbao. Los intereses geopolíticos y geoeconómicos compartidos por cuatro de los linajes que detentaban torres en la misma ruta hacia el puerto de Getxo, afianzaron de tal forma la vinculación de éstos durante la Baja Edad Media que, en el siglo xvi, después de varios enlaces matrimoniales, todos ellos acabaron fusionados en un solo tronco familiar 
Bipolaridad en el control de las principales rutas comerciales de Álava en el siglo xv. Mediante una cuidada política de alianzas y enlaces matrimoniales, dos de los principales linajes de la zona (los Mendoza al Oeste y los Guevara al Este), fueron haciéndose con el control de las torres que jalonaban los caminos

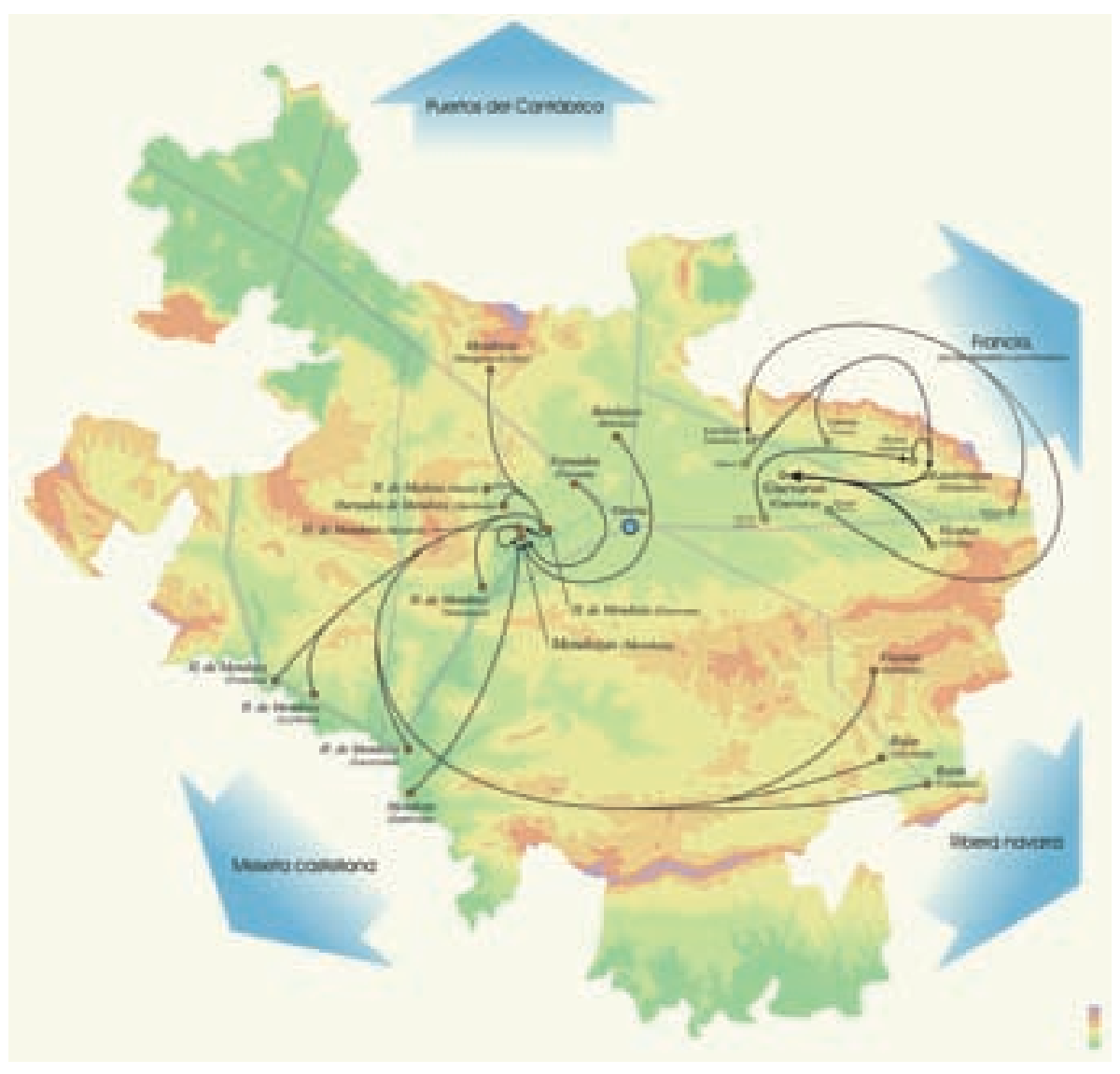

rencia de los diferentes parientes mayores, concentrados en hacer efectivo su dominio sobre ciertos segmentos del territorio. La forma en que se produjo este diseño no puede atribuirse a una estrategia macroespacial desarrollada por parte de los señores, sino a una paulatina estructuración —a escala cada vez mayor- de las rivalidades/afinidades entre aquellos.

En la medida en que los intereses de dos o más banderizos coincidían en un mismo ámbito geográfico, ambos estaban determinados a convertirse en aliados o en acérrimos adversarios. Pero además, dado que los recursos en disputa raramente se circunscribían a un punto concreto del espacio, sino que eran bienes con un acusado desarrollo en extensión - masas boscosas, cursos fluviales, vías de comunicación, etc.-, los acuerdos o los desencuentros tendían a encadenarse, dando lugar a redes de alianzas entre linajes y, cómo no, a la confrontación violenta de las parcialidades opuestas.

Esas confederaciones de amigos y enemigos, surgidas casi siempre dentro de una misma cuenca fluvial, en la medida en que se afianzaban localmente - con unos intereses comunes y bajo el liderazgo de un linaje dominante- empezaban a tener intereses sobre un espacio geográfico que excedía el marco donde se habían alineado inicialmente los dos polos de intereses contrarios entre familias vecinas.
Estas redes locales de linajes que compartían intereses se fueron organizando, a su vez, en redes extensas. En esta escala, el único recurso en disputa es el de la ruta comercial, con independencia de las diferentes características geográficas del territorio. Estas redes de escala mayor contaban también con el liderazgo superior de un pariente mayor y controlaban amplios tramos de las rutas comerciales que atravesaban el país de Sur a Norte. En esta escala superior, se constata de nuevo una tendencia al alineamiento bipolar en función de los intereses de los líderes de estas confederaciones por la explotación del comercio y de los recursos del territorio.

Pretendemos esbozar así un esquema organizativo de la conflictividad banderiza, perceptible a tres niveles. Uno, a escala vecinal —entre los señores de torres que se sitúan contiguamente-; dos, a escala de cuenca fluvial —entre asociaciones de nobles que comparten intereses-; y tres, a escala de ruta - entre confederaciones de asociaciones nobiliares que pretenden la explotación en beneficio propio del tráfico comercial de un itinerario-. Es necesario señalar que, aunque de forma diversa a la aquí propuesta, la cuestión de las diferentes escalas del enfrentamiento viene siendo tratada por la historiografía ya desde hace algunos años. Especialmente esclarecedores nos parecen los tres niveles de desarrollo del conflicto propuestos por Dacosta (2003: 310-370). 


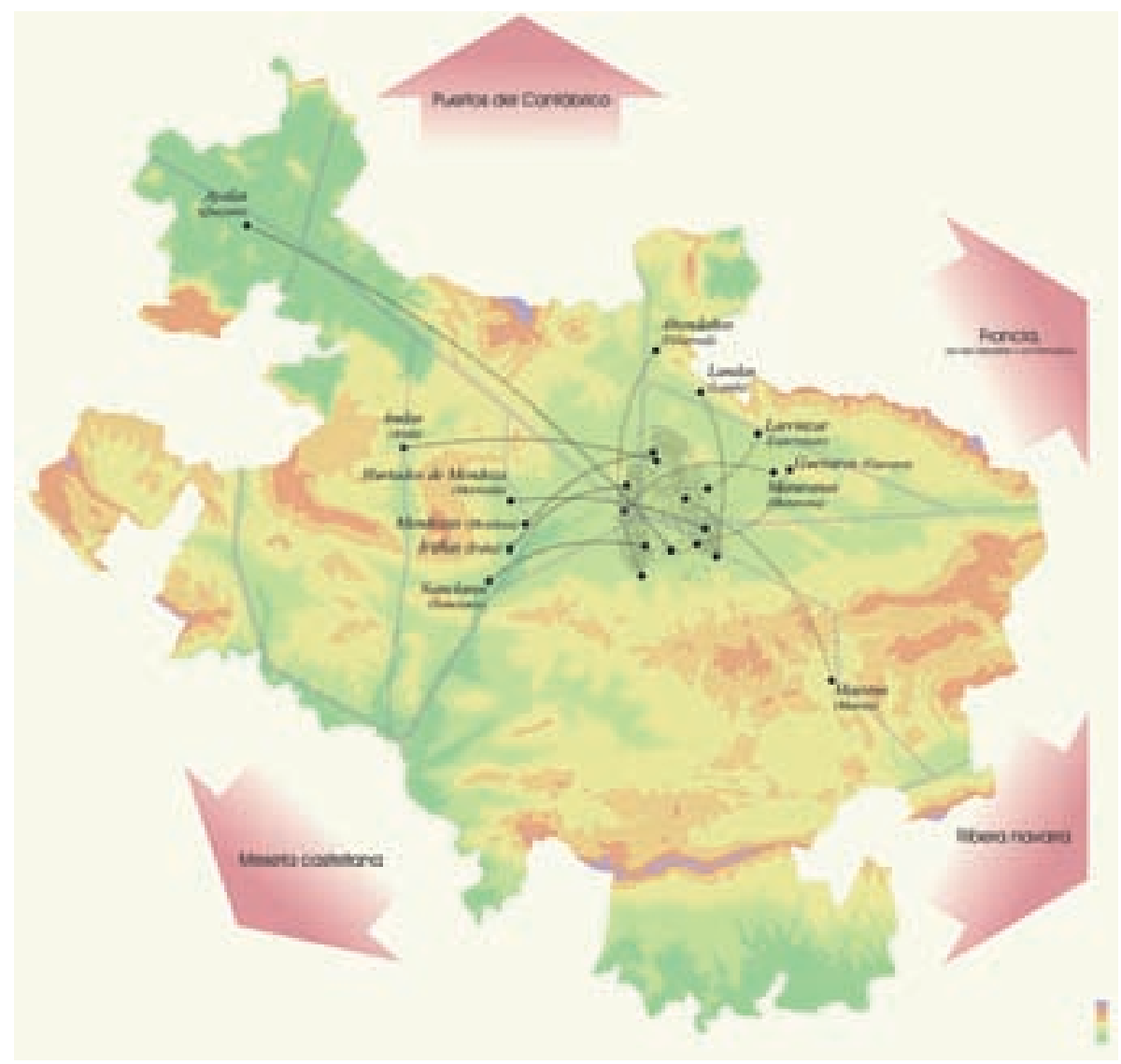

Inserción del S.A.B. en la villa. Solares originales de procedencia y puntos dentro de la villa de Vitoria donde se asentaron, a lo largo del siglo xv, los diferentes linajes de la Llanada Alavesa
En sintonía con la tendencia historiográfica actual, estamos convencidos de que el enfrentamiento banderizo es uno más dentro de un complejo conjunto de conflictos sociales con distintos niveles de expresión (DíAz DE DURANA, 1998: 40), aunque nos parece entrever bajo el clásico esquema de «oñacinos» contra "gamboinos» una importante cuota de realidad en la descripción del fenómeno. En nuestra opinión, a pesar de que no nos encontraríamos estrictamente ante un conflicto bilateral — con dos únicos bandos opuestos- sí que podríamos hablar de un conjunto de conflictos que se estructuran con base en un esquema bipolar.

La diferencia entre el bilateralismo y la bipolaridad se aprecia distinguiendo las escalas del enfrentamiento banderizo. Podría decirse que, considerando la conflictividad internobiliar horizontalmente - nivel por nivel- se constata siempre la existencia de una organización en torno a dos polos, o bandos, claramente definidos en función de diversos lazos socioeconómicos y también políticos. Este sistema de referencias horizontal es el que más fácilmente se percibe por parte del hombre medieval; los cronistas así lo transmiten y la historiografía ha tendido a recogerlo análogamente. Del mismo modo que los oñacinos son los opuestos a los gamboinos, los Avendaño son los opuestos de los Butrón e Iñigo de Guevara a Lope González de Mendoza.
Ahora bien, cuando consideramos la conflictividad banderiza en su desarrollo vertical -es decir, interescalar y diacrónicamente- observamos que la estructura del enfrentamiento se complica exponencialmente, debido a que el modo en que se arraciman o quiebran las alianzas entre señores facilitando la aparición de confederaciones más extensas, no responde a patrones determinados sino a contingencias dictadas por la coyuntura. Esta perspectiva vertical es difícilmente aprehensible por sus protagonistas, y muestra un perfil más inestable.

Inestabilidad y estabilidad son aspectos consustanciales del conflicto, siendo compatibles la percepción de una estructura bipolar de bandos con la cambiante realidad compositiva de los mismos.

\section{RED DE REDES:EL S.A.B. SE INSERTA EN LOS NÚCLEOS URBANOS}

Del «Nobiliario Alavés» de Fray Juan de Victoria: «Yen Vitoria se padecía con los bandos de Ayala, gamboino, y el de Calleja, oñacino, favoreciéndose cada uno de los comarcanos bandoleros, tiranizando la república y sus vecinos, robándoles con derramas, imposiciones, matándose y haciéndose todo el mal posible, usurpando los oficios de justicia, eligiendo cada bando alcalde, regidores, procurador, allende de la de los reyes, 
haciendo los Ayalas sus juntas en San Miguel y los Callejas en San Pedro.» VidaurRáZAGa E InCHAUsti, 1975: 63)

Venimos hablando de la estructuración del enfrentamiento banderizo, de un esquema bipolar que se expresa a diferentes escalas. Pues bien, quizá la villa sea uno de los ámbitos donde mejor se plasme este proceso de organización del conflicto, o al menos, parece que es uno de los lugares donde los cronistas lo perciben más nítidamente. Nos valdremos del ejemplo de la ciudad de Vitoria.

Cuando los parientes mayores desembarcan en el ámbito urbano no alteran sustancialmente su modo de vida y, a lo que parece, tampoco su forma de entender política y economía. En su mudanza desde el medio rural, exportan a las villas sus modos de dominio de la producción, insertando por lo tanto el sistema arquitectónico banderizo. Como sabemos, la eficacia de ese sistema estaba directamente relacionada con el control de ciertos puntos neurálgicos del espacio. Era natural, en consecuencia, que el banderizo tratase de aplicar los mismos principios geoestratégicos utilizados en origen a las peculiaridades del nuevo contexto.

A lo largo del siglo XIV, los señores comienzan a erigir sus torres privadas en medio del caserío protegido por las

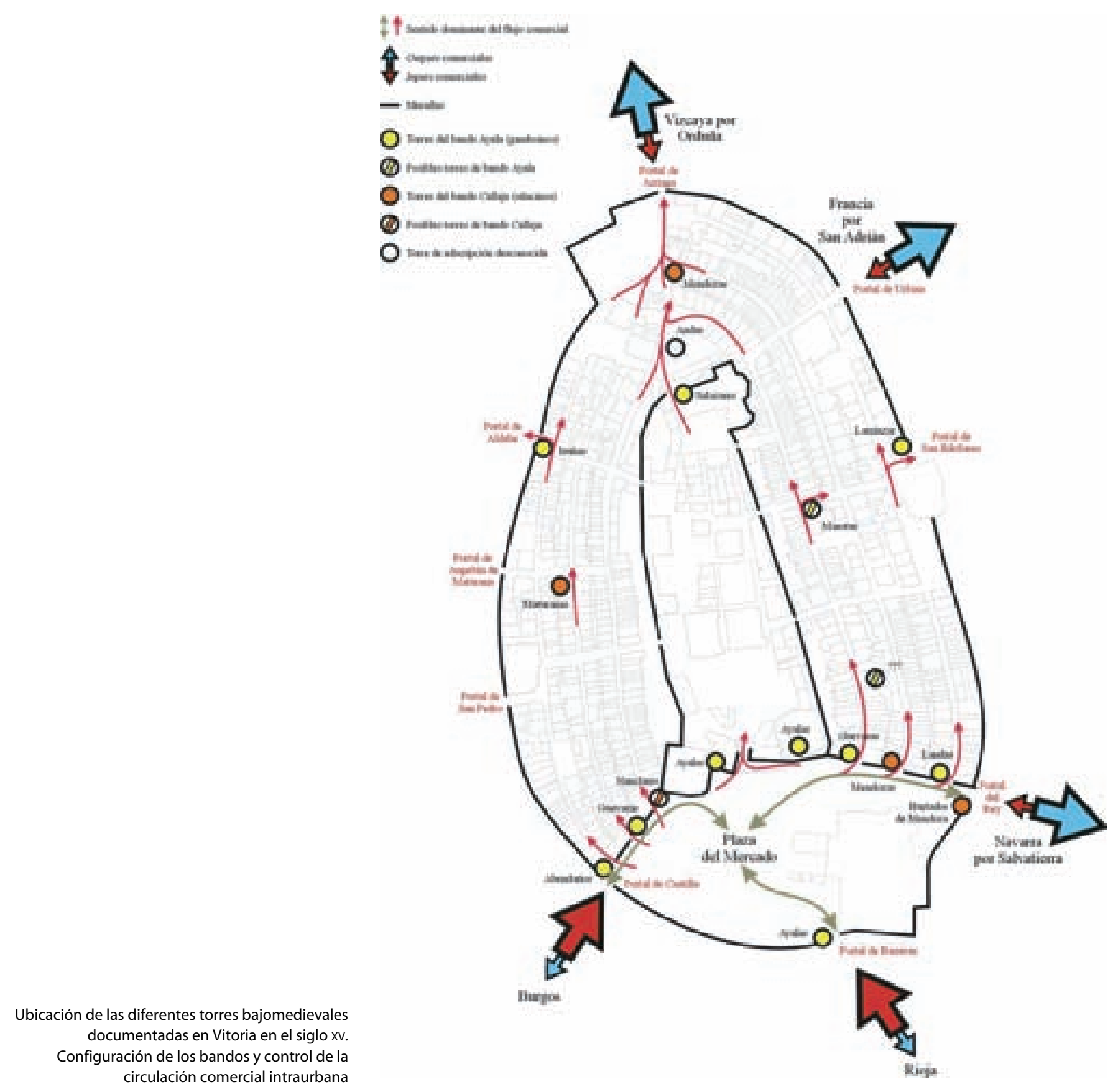


murallas, construyendo siempre en ubicaciones clave del tejido urbano. Cada uno de los linajes, en función de sus propios intereses y - cómo no- con base en las solidaridades parentelares, van obturando con sus fortificaciones los diferentes accesos de las murallas, tratando de decantar a su favor la mayor cantidad posible del flujo comercial que alimenta el mercado de la localidad.

El número de apellidos que se trasladan a la villa es variable según las poblaciones. Se observa, no obstante, cómo todos tienden a estructurarse en torno a dos polos. De nuevo nos señala el Padre Victoria: "Tenían los Ayalas su cabeza de bando en Correría, y los Callejas en Zapatería en las casas que fueron de Juan Ruiz de Vergara» (VIDAURRÁZAGA E INCHAUSTI, 1975: 64). Como se comprueba en Vitoria, un polo liderado por el linaje de los Ayala se opondrá a otro organizado en torno a la familia de los Maturana —cabeza del bando de los Callejas-, una articulación bipolar de la que no se sustrae ningún noble. Analizando el urbanismo de la época, se observa cómo esta estructuración socio-política tiene su perfecta plasmación sobre el espacio físico de la villa. Vitoria se convierte en una réplica a menor escala de la propia Llanada Alavesa, reproduciendo el mismo esquema espacial del conflicto, pero ahora dentro de las murallas.

\section{La villa como sistema múltiple de enrutación}

Como decimos, los métodos de captación del excedente campesino y el control de los ciclos productivos en el interior de la ciudad siguieron siendo muy similares a los empleados hasta el momento. Se trataba, en primera instancia, de dominar también los molinos y ferrerías dependientes de la comunidad - por ejemplo, los Álava en Vitoria a finales del siglo XV aparecen como propietarios de una de las principales ruedas de la villa-; en segundo lugar, captar las imposiciones decimales — para ganar derechos los distintos linajes vitorianos comienzan a insertarse en los cabildos de las diferentes parroquias y a patrocinar la reedificación de sus capillas mayores, añadiendo a las antiguas fábricas capillas privadas y espectaculares bóvedas en piedra—; y, finalmente, se trataba también de gestionar el flujo comercial, pero ya no de una forma subsidiaria o parasitaria desde las afueras del sistema urbano, sino en su propio corazón, junto al mercado.

Los linajes que se trasladan al interior de la villa no pierden el dominio de su solar de origen, todo lo contrario. Contando ya con una retícula de fortificaciones que administra segmentos clave de las rutas comerciales regionales -es decir, administrando los rendimientos de los diferentes complejos productivos que poseen en el medio rural-, trasladan su centro de operaciones a la urbe, conscientes de que la infraestructura que ésta ofrece aumenta las posibilidades de gestión/apropiación del flujo mercantil. La concentración urbana no sólo permite un control cercano del mercado, sino que además fomenta la interactuación - amistosa o conflictiva - entre las familias que tratan de dominarlo.

Desde este punto de vista, la ciudad preexistente se ve alterada en su configuración por la aparición de un cuantioso grupo de gestores de enrutación - como son las torres - cada uno de los cuales controla los flujos mercantiles desde los accesos a través de las murallas, según el código afín a sus propietarios. Así, una multiplicidad de criterios diferenciados se irá estructurando con base en los polos de los bandos, dando lugar finalmente a lo que podríamos denominar como «crónico trastorno bipolar» de la villa bajomedieval.

Este cuadro, con una ciudad plagada de torres, violentada en su estructuración primitiva, preludiará, paradójicamente, el ocaso de estas últimas. Ya antes del período de crisis bajomedieval se habían demostrado - como corolario de todo un sistema arquitectónico de dominación- dispositivos eficaces en el control de los recursos del territorio. Fue precisamente su éxito el que las fue aproximando - junto con sus constructores- a los nodos neurálgicos del sistema urbano, propiciando una postrera fusión mediante la catarsis de la violencia de los bandos. Sobre la estructura de las torres de finales del siglo XV y principios del siglo XVI, se edificarán los palacios de una nobleza sintetizada, que asimismo había comenzado a construir nuevos marcos sociopolíticos de concentración del poder: de la destilación de los bandos surgirá la nueva organización concejil.

\section{Bibliografía}

Aragón RuAno, A., 2001, El bosque guipuzcoano en la Edad Moderna: aprovechamiento, ordenamiento legal y conflictividad, Munibe, n. ${ }^{\circ} 14$ (suplemento).

Avello, J.L., 1991, Las torres señoriales de la Baja Edad Media asturiana, León.

Azkarate, A., Palacios, V., 1996, Puentes de Alava, Vitoria.

AZKARATE, A., LASAGABASTER, J.I., La arqueología y la recuperación de las «arquitecturas olvidadas», IV Congreso Internacional: Restaurar la Memoria», Valladolid, 2004 (e.p.).

BAREL, Y., 1981, La ciudad medieval. Sistema social-Sistema urbano, Madrid.

BAZÁN, I., 1998, El refugio de la delincuencia señorial. Torres y casas fuertes en el País Vasco: el ejemplo de la torre de Berna, Sancho el Sabio, n.o 8 , pp. 23-50.

BoIS, G., 2001, La gran depresión medieval: siglos XIV y XV: El precedente de una crisis sistémica, Madrid.

Catalán Martínez, E., 2000, El precio del Purgatorio. Los ingresos del clero vasco en la Edad Moderna, Bilbao.

Dacosta, A., 2002, Las fuentes de renta del linaje Salazar. Aportación al estudio de las haciendas nobiliarias en la Corona de Castilla durante la Baja Edad Media, en Díaz de Durana, J.R., Reguera, I. (Eds.), Lope 
García de Salazar: banderizo y cronista. Actas de las II Jornadas de Estudios Históricos de la Villa de Portugalete, Portugalete, pp. 43-64.

Dacosta, A., 2003, Los linajes de Bizkaia en la Baja Edad Media: parentesco y conflicto, Bilbao.

Díaz de Durana, J.R., 1986, Álava en la Baja Edad Media. Crisis, recuperación y transformaciones socioeconómicas., Vitoria-Gasteiz.

Díaz de Durana, J.R., 1998, Historia y presente del tratamiento historiográfico sobre la lucha de bandos en el País Vasco. Balance y perspectivas al inicio de una nueva investigación, en La lucha de bandos en el País Vasco, de los parientes mayores a la hidalguía universal: Guipuzcoa, de los bandos a la Provincia (siglos XIV a XVI), Bilbao, pp. 21-46.

DíAZ DE DuRAnA, J.R., 2000, Parientes mayores y señores de la guerra guipuzcoana., en LEMA PUEYO, J.A. et al., Los señores de la guerra y de la tierra: Nuevos textos para el estudio de los parientes mayores guipuzcoanos (1256-1548), Donostia-San Sebastián, pp. 45-73.

Diez DE SAlaZAR, L.M., 1983, Ferrerías en Guipúzcoa (siglos XIV-XVI). Historia, Donosita-San Sebastián.

DomíngueZ, I.C., SÁnchez ZufiaurRe, L., 2001, De la teoría a la práctica: Aplicación del método de lectura estratigráfica a la Torre de Orgaz, en Fontecha (Álava), Actas del V Congreso de Arqueología Medieval Española, Valladolid, pp. 213-220.

FERNÁNDEZ DE LARREA, J.A., 2000, Los señores de la guerra en la Guipúzcoa bajomedieval, en LEMA PUEYO, J.A. et al., Los señores de la guerra y de la tierra: Nuevos textos para el estudio de los parientes mayores guipuzcoanos (1256-1548), Donostia-San Sebastián.

FERNÁNDEZ GaLIANO, L., 1991, El fuego y la memoria. Sobre arquitectura y energía, Madrid.

Gallopin, G.C., Funtowicz, S., O'Connor, M., Ravetz, J., 2001, Science for the twenty-first century: from social contract to the scientific core, Int, Journal Social Science, 168: 219-229 (www.unesco.org/issj) («Una ciencia para el siglo XXI: del contrato social al núcleo científico, http://www.campus-oei.org/salactsi/ctsdoc.htm).

García de Cortázar, F., Montero, M., 1999, Ferrerías, en Diccionario de Historia del País Vasco, Donostia-San Sebastián, pp. 271-286.

García Camino, I., 2002, Arqueología y poblamiento en Bizkaia. Siglos VI-XII. La configuración de la sociedad feudal, Bilbao.

GarCía GÓmEZ, I., 2003, Claves para el conocimiento de la configuración espacial de una torre banderiza: la Torre de Murga (siglos XIV-XV), Arqueología de la Arquitectura, n. ${ }^{\circ}$ 2, pp. 131-138.

GarCÍA GÓMEZ, I., SÁnchez PinTo, I., 2003, Documentación estratigráfica y análisis histórico de la torre de Martiartu (Erandio, Bizkaia), Arkeoikuska 02, pp. 467-469.

García GÓmez I., SÁnchez PinTo I., 2004, Torre de Madariaga (Busturia), Arkeoikuska 03, pp. 285-292.

GonZÁlez Cembellín, J.M., 2002, Las casas-torre en Bizkaia de los siglos XV y XVI. El caso portugalujo, en DíaZ De Durana J.R., RegueRA I. (Eds.), Lope García de Salazar: banderizo y cronista. Actas de las II Jornadas de Estudios Históricos de la Villa de Portugalete, Portugalete, pp. 65-93.
GonzÁlez Cembellín, J.M., 2004, Torres de las Encartaciones, Bilbao

González Mínguez, C., Hoz Díaz de Alda, M.C. DE la, 1991, La infraestructura viaria bajomedieval en Álava. Documentos para su estudio, Bilbao.

GonzÁlez Mínguez, C., 1989, El portazgo en la Edad Media. Aproximación a su estudio en la Corona de Castilla, Bilbao.

IBÁÑEZ GÓmEZ, M. et al., 1992, Arqueología industrial en Álava, Bilbao.

JimÉNEZ, J.M., 1993, Torres y castillos de la Cantábria medieval, Santander.

LARREA Beobide, A., 2000, El patronato laico vizcaíno en el Antiguo Régimen, Bilbao.

LEMA PuEYO, J.A. et al., 2000, Los señores de la guerra y de la tierra: Nuevos textos para el estudio de los parientes mayores guipuzcoanos (1256-1548), Donostia-San Sebastián.

López Alsina, F., 2002, El encuadramiento eclesiástico como espacio de poder. De la parroquia al obispado, en IgLESIA DuARTE, J.I. DE LA (Coord.), Los espacios de poder en la España medieval. XII Semana de Estudios Medievales de Nájera, Logroño.

Mannoni, T., Giannichedda, E., 2003, Arqueología de la producción, Barcelona.

MARÍN SÁNCHEZ, A.M. (Ed.), Istoria de las bienandanzas e fortunas de Lope García de Salazar, Lemir, consulta del 20 de Enero, 2005, de http://parnaseo.uv.es/Lemir/Textos/bienandanzas/Menu.htm.

MARTí, R., 1988, Hacia una arqueología hidráulica: la génesis del molino feudal en Cataluña, en BARCeló M. et al., Arqueología Medieval. En las afueras del "medievalismo", Barcelona.

MarTín, C., 2002, Ruedas y molinos en Álava, Ohitura, n. ${ }^{o} 10$ (extraordinario).

Orella Unzué J.L., Estévez X., 1996, Casas-torre y palacios de Guipúzcoa, Donosita-San Sebastián.

PAlacios, V., 2001, El patrimonio artístico del Valle de Ayala: Torres, Palacios y puentes, en GARCía FernándeZ, E. (Coord.), La tierra de Ayala. Actas de las Jornadas de Estudios Históricos en conmemoración del 600 Aniversario de la construcción de la Torre de Quejana, Vitoria-Gasteiz, pp. 163-189.

Portilla Vitoria, M.J., 1978, Torres y casas fuertes en Álava, VitoriaGasteiz.

Portilla Vitoria, M.J., 1988, Quejana. Solar de los Ayala, Vitoria-Gasteiz.

RYBZYNSKY, W., 2001, La casa. Historia de una idea, Madrid.

Sáenz de Santamaría, A., 1985, Molinos hidráulicos en el Valle Alto del Ebro (siglos XI-XV), Vitoria-Gasteiz.

SaILHAN, P., 1991, La fortification. Historie et dictionnaire, Paris

SÁNCHEZ, J.E., 1991, Espacio, economía y sociedad, Madrid.

VidaurráZaga E InChausti, J.L. DE (Ed.), 1975, Nobiliario de Fray Juan de Victoria. Siglo XVI, Bilbao.

YbarRa y Bergé, J. DE, GaRmendia, P. DE, 1946, Torres de Vizcaya, Madrid.

YRIZAR J. DE, 1929, Las casas vascas, Bilbao. 